IP Periodica Polytechnica Civil Engineering

60(4), pp. 531 546,2016 DOI: $10.3311 /$ PPci.8475

Creative Commons Attribution (1)

RESEARCH ARTICLE

\section{A Comparative Study of the Shell Element and Strip Model Methods for Analysis of Steel Plate Shear Wall Structures}

\author{
Masoumeh Gholipour, Mohammad Mehdi Alinia \\ Received 06-08-2015, revised 01-02-2016, accepted 02-02-2016
}

\begin{abstract}
Shell element and strip model are the two available numerical methods in the analysis of steel plate shear wall (SPSW) structures. The shell element model provides excellent prediction of the behavior of SPSWs. However, when the number of elements increases, especially in high-rise frames, the method becomes time consuming and produces convergence complications. In such cases, the strip model is commonly used as an alternative method. In the literature, the evaluation of the strip model has only been carried out for up to four-story SPSW structures. In the present study, fourteen low-to high-rise SPSW frames having 4, 7, 10 and 13 stories with different bay widths of 2, 3, 6 and $9 \mathrm{~m}$ are designed and modeled using shell element and strip methods. The pushover analysis results show that the accuracy of strip model is affected by the number of story levels as well as the bay width. The use of beam element in modeling frame members is shown to have considerable effects on the results of the strip model. The panel zones should be modeled as effectively rigid regions in the strip model; and the slenderness ratio of frame members should be considered. It is also found that the distribution of story shear between infill plates and frame members are quite different in the two modeling methods. Furthermore, modifications to improve the accuracy of the strip model are recommended in this paper.
\end{abstract}

\section{Keywords \\ Steel plate shear walls $\cdot$ shell element model $\cdot$ strip model}

\section{Masoumeh Gholipour}

Department of Civil Engineering, Amirkabir University of Technology, 424 Hafez Ave., Tehran 15875-4413, Iran

\section{Mohammad Mehdi Alinia}

Department of Civil Engineering, Amirkabir University of Technology, 424 Hafez Ave., Tehran 15875-4413, Iran

e-mail: m.alinia@aut.ac.ir

\section{Introduction}

The steel plate shear wall (SPSW) configuration has been widely used as a lateral load resisting system in the regions of high seismicity. A typical SPSW consists of infill steel plates connected to the beams, known as the horizontal boundary elements (HBEs); and to the columns, as the vertical boundary elements (VBEs). All HBE-VBE connections are of moment resisting type. From the numerous analytical and experimental investigations conducted worldwide, it has been shown that SPSWs have many advantages such as high initial stiffness and strength, substantial ductility, fast construction, reduction of seismic mass and increased useable floor plan. The overall building cost of SPSW structures is also shown to be reduced in comparison with other lateral load resisting systems [1-4].

Many numerical researches have been carried out to study the behavior of SPSW systems. Amongst various proposed analytical models, two methods are frequently used by researchers and practicing engineers. These methods are known as the shell element model and the strip model. In the shell element model, infill plates, HBEs and VBEs are all modeled via the shell elements. Behbahanifard et al. [5] studied the accuracy of the shell element method via comparing the results of FE analysis with the test results of two 3- and 4-story SPSW specimens. They observed that the shell element model agrees well with test results; and is able to capture all essential features of the behavior of SPSW system. According to Park et al. [6], by using the shell element model, a good prediction of the behavior of SPSW test specimens can be obtained. Habashi and Alinia [7] studied the characteristics of wall-frame interaction in 1-story SPSW frames, utilizing shell element method and pushover analysis. Gholipour and Alinia $[\overline{8}]$ investigated the effect of loading pattern on the pushover analysis response of multi-story SPSW frames modeled by the shell element method. The evaluation of M-PFI (Modified Plate Frame Interaction) design methodology was performed by Kharrazi et al. [9] using shell element method and pushover analysis of 3-, 9- and 27-story SPSW structures. Bhowmick et al. [10 11] studied the seismic characteristics of SPSW systems by performing frequency and time-history analyses of 1- to 15-story SPSW frames modeled by the shell element 
method.

The strip model, on the other hand, was developed in 1983 by Thorburn et al. [12] as an alternative analytical model. In the strip model, infill plates and boundary frame members are modeled respectively by tension-only truss elements and beam elements. Verification of the strip model was first performed by Timler and Kulak [13] by comparing the strip model results with those obtained from the test of two full-scale 1-story SPSW specimens. Acceptable correlation was found between analytically predicted behaviors with those of test results. Tromposch and Kulak [14] tested another full-scale 1-story SPSW specimen and compared the test results with those of the strip model. They observed that the strip model gives conservative estimates of both initial stiffness and ultimate capacity. Similar studies were performed by Lubell [15] and Driver [16] on the accuracy of strip model using the test results of 1- and 4-story SPSW specimens. They concluded that the strip model provides reasonable estimate of the response of SPSWs; however, it underestimates both the elastic stiffness and the load capacity of SPSW system.

In spite of discrepancies found between the results of the strip model with those of the experiments, the accuracy of model has been accepted for practical purposes; and the Canadian steel design standard [17] and AISC-341 [18] recommend its use for the analysis of SPSW structures. The strip model has been utilized by many researchers to study the behavior of SPSW structures; for example see Berman [19] and Gholipour et al. [20]. Shell element model, on the other hand, provides excellent prediction of the behavior of SPSW structures. However, when the number of elements increases, especially in high-rise SPSW frames, such modeling method becomes time consuming and produces convergence complications. The shell element model also cannot be easily utilized by practicing engineers using commercial software programs such as SAP2000 [21].

In the previous researches, the tallest SPSW structure considered for the evaluation of the strip model was the Driver's 4-story test specimen with an overall height of $7.4 \mathrm{~m}$. In the present study, fourteen SPSW frames having 4, 7, 10 and 13 stories with different bay widths of 2, 3, 6 and $9 \mathrm{~m}$ are considered and modeled via both shell element and strip model methods. The obtained results of the strip model are compared to those of the shell element method. Comparison is based on the pushover curves considering the initial stiffness and load carrying capacity. The distribution of story shear between infill plates and VBEs; and the internal forces of VBEs are also investigated. Results are discussed in detail; the source of discrepancies between the two modeling methods is identified; and the modifications required to improve the accuracy of the strip model are recommended.

\section{Method of study}

\subsection{Geometric specifications of frames}

Fourteen 4-, 7-, 10-, and 13-story SPSW frames with bay widths of 2, 3, 6 and $9 \mathrm{~m}$ were considered in this study. The story height was presumed to be $3.6 \mathrm{~m}$ in all frames. The dead, live and seismic loads were calculated per ASCE 7-10 [22] for a building with an overall floor plan dimensions of $17 \times 17 \mathrm{~m}^{2}$ as depicted in Fig. 1. The building design included two SPSWs on the perimeter of each direction. All beam-column connections were considered to be shear type, except those in the bays of SPSWs which were designed to be moment resisting, according to the requirements of AISC-341 [18]. Accordingly, the adjoining frames outside the SPSW bays are gravity load resisting frames and were not incorporated in design and analysis.

\subsection{Material properties}

The ASTM-A36 and ASTM-A572 steel material properties were respectively used for infill plates and frame members. The presumed nonlinear stress-strain characteristics of materials are given in Fig. 2. The yield stress of infill plate (325 MPa) was selected less than that of frame members $(385 \mathrm{MPa})$ to reduce the forces induced by infill plates on the HBEs and VBEs.

\subsection{Design procedure}

All frames were designed according to the AISC-341 [18] and the AISC-360 [23] rules and specifications. Design of frames was performed on a site class D soil; and adjusted maximum considered earthquake spectral response parameters at 0.2 and $1 \mathrm{~s}$ periods, $S_{M S}$ and $S_{M 1}$, were $1.61 \mathrm{~g}$ and $1.19 \mathrm{~g}$ respectively. The resulting design spectral acceleration parameters at 0.2 and $1 \mathrm{~s}, S_{D S}$ and $S_{D 1}$, were $1.07 \mathrm{~g}$ and $0.79 \mathrm{~g}$ respectively. The calculation of design seismic base shear and the distribution of seismic forces along the height of frames were carried out according to the equivalent lateral force procedure specified in the ASCE 7-10 [22].

The thickness of infill plates was calculated to resist the full story shear. HBEs and VBEs were then designed to resist forces induced by the fully yielded infill plates according to the principles of capacity design method per AISC-341 [18]. The HBEVBE moment connection details are composed of reduced beam sections (RBS) to ensure the inelastic action at HBE ends away from the face of VBEs.

The as-designed infill plate thicknesses and sections of HBEs and VBEs are given in Tables 1-4. HBEs were selected from the W-section type and VBEs were selected from box sections since $\mathrm{W}$-sections did not fulfill the capacity design requirements for VBEs in the high-rise SPSWs. The box sections are named according to their widths and thicknesses in millimeters. For example, the Box $300 \times 20$ is a square section with the width and height of $300 \mathrm{~mm}$, and web thickness of $20 \mathrm{~mm}$.

\subsection{FE modeling}

Frames were modeled via shell element and strip methods using the ABAQUS finite element software package [24]; and analyzed via pushover analysis. In the shell element method, infill plates, HBEs and VBEs were modeled with the shell element 
Tab. 1. Design sections of the 4-story SPSW frames

\begin{tabular}{|c|c|c|c|c|c|c|c|c|c|c|c|c|}
\hline \multirow{3}{*}{ Level } & \multicolumn{4}{|c|}{ Plate Thickness (mm) } & \multicolumn{4}{|c|}{ HBE } & \multicolumn{4}{|c|}{ VBE } \\
\hline & \multicolumn{12}{|c|}{ Bay Width (m) } \\
\hline & 2 & 3 & 6 & 9 & 2 & 3 & 6 & 9 & 2 & 3 & 6 & 9 \\
\hline 4 & 1.95 & 1.18 & 0.56 & 0.37 & W8 $\times 67$ & $W 8 \times 58$ & W12 $\times 170$ & W14 × 370 & $\begin{array}{c}\text { Box } \\
350 \times 25\end{array}$ & $\begin{array}{c}\text { Box } \\
300 \times 20\end{array}$ & $\begin{array}{c}\text { Box } \\
350 \times 35\end{array}$ & $\begin{array}{c}\text { Box } \\
450 \times 45\end{array}$ \\
\hline 3 & 3.55 & 2.10 & 0.99 & 0.65 & $\mathrm{~W} 10 \times 112$ & $W 8 \times 58$ & W12 × 136 & W12 × 336 & $\begin{array}{c}\text { Box } \\
400 \times 30\end{array}$ & $\begin{array}{c}\text { Box } \\
300 \times 30\end{array}$ & $\begin{array}{c}\text { Box } \\
400 \times 30\end{array}$ & $\begin{array}{c}\text { Box } \\
550 \times 40\end{array}$ \\
\hline 2 & 4.65 & 2.75 & 1.27 & 0.84 & $\mathrm{~W} 10 \times 112$ & $W 8 \times 58$ & W12 × 96 & W12 × 252 & $\begin{array}{c}\text { Box } \\
450 \times 35\end{array}$ & $\begin{array}{c}\text { Box } \\
350 \times 25\end{array}$ & $\begin{array}{c}\text { Box } \\
400 \times 30\end{array}$ & $\begin{array}{c}\text { Box } \\
550 \times 40\end{array}$ \\
\hline 1 & 5.25 & 3.10 & 1.43 & 0.94 & $\mathrm{~W} 10 \times 112$ & $W 8 \times 58$ & W12 $\times 96$ & $W 12 \times 152$ & $\begin{array}{c}\text { Box } \\
450 \times 40\end{array}$ & $\begin{array}{c}\text { Box } \\
350 \times 25\end{array}$ & $\begin{array}{c}\text { Box } \\
400 \times 30\end{array}$ & $\begin{array}{c}\text { Box } \\
550 \times 40\end{array}$ \\
\hline
\end{tabular}

Tab. 2. Design sections of the 7-story SPSW frames

\begin{tabular}{|c|c|c|c|c|c|c|c|c|c|c|c|c|}
\hline \multirow{3}{*}{ Level } & \multicolumn{4}{|c|}{ Plate Thickness (mm) } & \multicolumn{4}{|c|}{ HBE } & \multicolumn{4}{|c|}{ VBE } \\
\hline & \multicolumn{12}{|c|}{ Bay Width (m) } \\
\hline & 2 & 3 & 6 & 9 & 2 & 3 & 6 & 9 & 2 & 3 & 6 & 9 \\
\hline 7 & 2.15 & 1.30 & 0.62 & 0.41 & W8 $\times 58$ & W8 $\times 58$ & $\mathrm{~W} 12 \times 190$ & W14 × 398 & $\begin{array}{c}\text { Box } \\
350 \times 25\end{array}$ & $\begin{array}{c}\text { Box } \\
300 \times 20\end{array}$ & $\begin{array}{c}\text { Box } \\
350 \times 35\end{array}$ & $\begin{array}{c}\text { Box } \\
500 \times 40\end{array}$ \\
\hline 6 & 4.30 & 2.50 & 1.15 & 0.76 & W8 $\times 67$ & W8 $\times 58$ & $\mathrm{~W} 12 \times 152$ & W14 × 342 & $\begin{array}{c}\text { Box } \\
450 \times 35\end{array}$ & $\begin{array}{c}\text { Box } \\
350 \times 30\end{array}$ & $\begin{array}{c}\text { Box } \\
400 \times 40\end{array}$ & $\begin{array}{c}\text { Box } \\
550 \times 50\end{array}$ \\
\hline 5 & 6.15 & 3.55 & 1.62 & 1.07 & $\mathrm{~W} 10 \times 112$ & W10 $\times 77$ & W12 $\times 152$ & W14 × 342 & $\begin{array}{c}\text { Box } \\
500 \times 45\end{array}$ & $\begin{array}{c}\text { Box } \\
450 \times 30\end{array}$ & $\begin{array}{c}\text { Box } \\
450 \times 45\end{array}$ & $\begin{array}{c}\text { Box } \\
600 \times 55\end{array}$ \\
\hline 4 & 7.70 & 4.40 & 1.98 & 1.30 & $\mathrm{~W} 10 \times 112$ & $W 10 \times 77$ & $W 12 \times 120$ & W12 $\times 279$ & $\begin{array}{c}\text { Box } \\
550 \times 55\end{array}$ & $\begin{array}{c}\text { Box } \\
450 \times 45\end{array}$ & $\begin{array}{c}\text { Box } \\
500 \times 40\end{array}$ & $\begin{array}{c}\text { Box } \\
600 \times 60\end{array}$ \\
\hline 3 & 9.20 & 5.05 & 2.28 & 1.48 & $\mathrm{~W} 10 \times 112$ & $W 10 \times 88$ & $\mathrm{~W} 12 \times 120$ & W12 $\times 279$ & $\begin{array}{c}\text { Box } \\
600 \times 60\end{array}$ & $\begin{array}{c}\text { Box } \\
500 \times 45\end{array}$ & $\begin{array}{c}\text { Box } \\
500 \times 40\end{array}$ & $\begin{array}{c}\text { Box } \\
600 \times 60\end{array}$ \\
\hline 2 & 10.30 & 5.42 & 2.45 & 1.60 & $\mathrm{~W} 10 \times 112$ & $W 10 \times 88$ & W10 $\times 77$ & W12 $\times 170$ & $\begin{array}{c}\text { Box } \\
650 \times 55\end{array}$ & $\begin{array}{c}\text { Box } \\
500 \times 45\end{array}$ & $\begin{array}{c}\text { Box } \\
500 \times 40\end{array}$ & $\begin{array}{c}\text { Box } \\
600 \times 60\end{array}$ \\
\hline 1 & 11.10 & 5.80 & 2.58 & 1.65 & $\mathrm{~W} 10 \times 112$ & $W 10 \times 100$ & W10 × 77 & $W 12 \times 96$ & $\begin{array}{c}\text { Box } \\
650 \times 55\end{array}$ & $\begin{array}{c}\text { Box } \\
500 \times 45\end{array}$ & $\begin{array}{c}\text { Box } \\
500 \times 40\end{array}$ & $\begin{array}{c}\text { Box } \\
600 \times 60\end{array}$ \\
\hline
\end{tabular}

Tab. 3. Design sections of the 10 -story SPSW frames

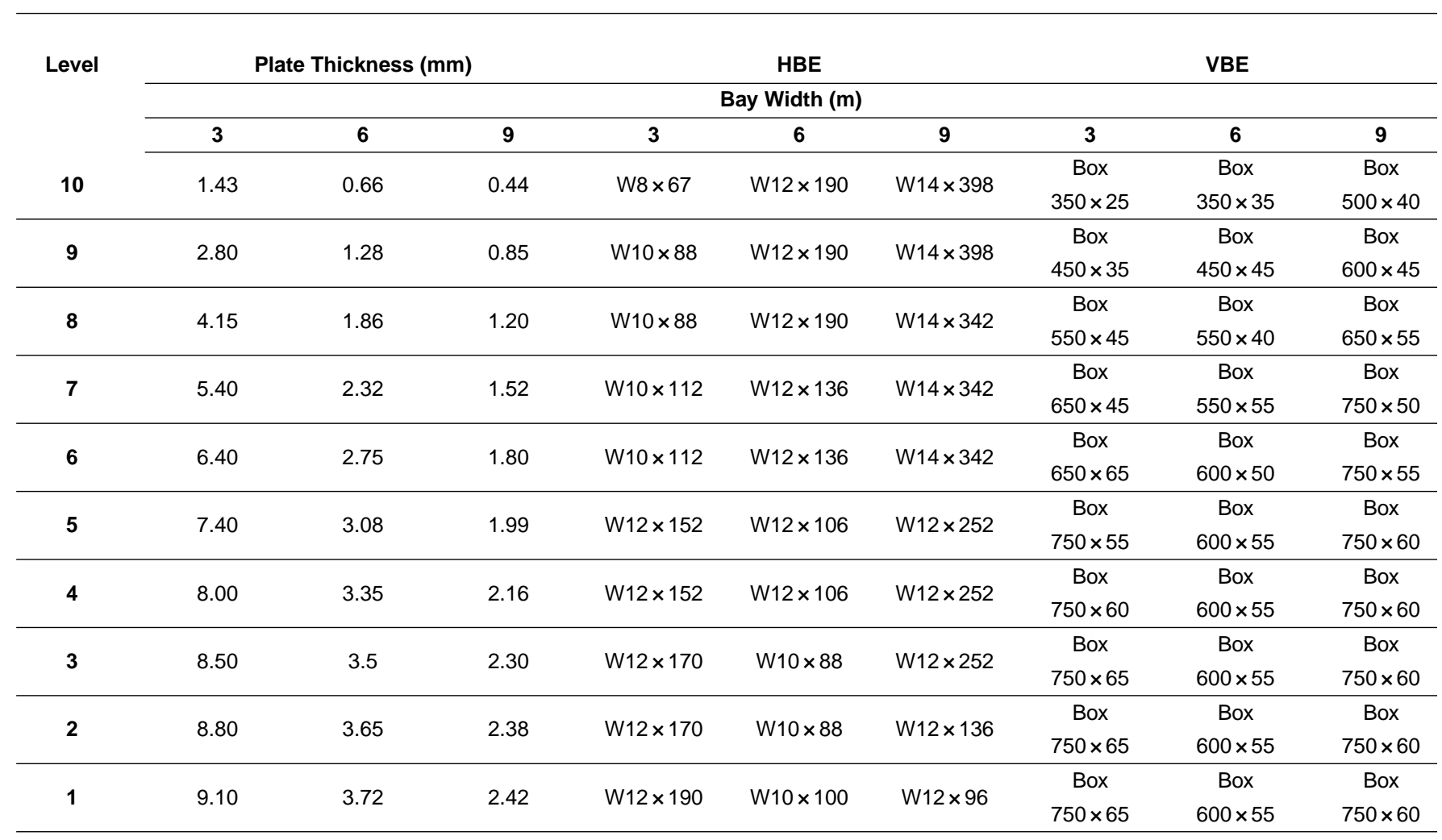


Tab. 4. Design sections of the 13-story SPSW frames

\begin{tabular}{|c|c|c|c|c|c|c|c|c|c|}
\hline \multirow{3}{*}{ Level } & \multicolumn{3}{|c|}{ Plate Thickness (mm) } & \multicolumn{3}{|c|}{ HBE } & \multicolumn{3}{|c|}{ VBE } \\
\hline & & & & & $y$ Width (m) & & & & \\
\hline & 3 & 6 & 9 & 3 & 6 & 9 & 3 & 6 & 9 \\
\hline 13 & 1.53 & 0.70 & 0.47 & W8 $\times 67$ & W12 × 190 & W14 × 426 & $\begin{array}{c}\text { Box } \\
400 \times 30\end{array}$ & $\begin{array}{c}\text { Box } \\
400 \times 30\end{array}$ & $\begin{array}{c}\text { Box } \\
500 \times 40\end{array}$ \\
\hline 12 & 3.15 & 1.38 & 0.91 & $\mathrm{~W} 10 \times 100$ & W12 × 190 & $W 14 \times 426$ & $\begin{array}{c}\text { Box } \\
550 \times 40\end{array}$ & $\begin{array}{c}\text { Box } \\
500 \times 40\end{array}$ & $\begin{array}{c}\text { Box } \\
600 \times 55\end{array}$ \\
\hline 11 & 4.80 & 1.98 & 1.32 & $W 10 \times 100$ & W12 × 190 & $W 14 \times 426$ & $\begin{array}{c}\text { Box } \\
700 \times 45\end{array}$ & $\begin{array}{c}\text { Box } \\
550 \times 50\end{array}$ & $\begin{array}{c}\text { Box } \\
700 \times 60\end{array}$ \\
\hline 10 & 6.40 & 2.60 & 1.68 & $\mathrm{~W} 10 \times 112$ & W12 × 190 & W14 × 342 & $\begin{array}{c}\text { Box } \\
800 \times 55\end{array}$ & $\begin{array}{c}\text { Box } \\
650 \times 50\end{array}$ & $\begin{array}{c}\text { Box } \\
750 \times 65\end{array}$ \\
\hline 9 & 7.90 & 3.10 & 1.98 & $\mathrm{~W} 10 \times 112$ & W12 × 152 & $W 14 \times 342$ & $\begin{array}{c}\text { Box } \\
900 \times 60\end{array}$ & $\begin{array}{c}\text { Box } \\
650 \times 60\end{array}$ & $\begin{array}{c}\text { Box } \\
800 \times 65\end{array}$ \\
\hline 8 & 9.00 & 3.55 & 2.25 & W12 × 170 & W12 × 152 & W12 × 336 & $\begin{array}{c}\text { Box } \\
900 \times 75\end{array}$ & $\begin{array}{c}\text { Box } \\
700 \times 60\end{array}$ & $\begin{array}{c}\text { Box } \\
800 \times 75\end{array}$ \\
\hline 7 & 10.40 & 3.93 & 2.50 & $W 12 \times 170$ & $\mathrm{~W} 12 \times 120$ & $\mathrm{~W} 12 \times 336$ & $\begin{array}{c}\text { Box } \\
1000 \times 70\end{array}$ & $\begin{array}{c}\text { Box } \\
700 \times 65\end{array}$ & $\begin{array}{c}\text { Box } \\
800 \times 80\end{array}$ \\
\hline 6 & 11.20 & 4.23 & 2.70 & W12 × 170 & $\mathrm{~W} 12 \times 120$ & W12 × 252 & $\begin{array}{c}\text { Box } \\
1000 \times 75\end{array}$ & $\begin{array}{c}\text { Box } \\
700 \times 70\end{array}$ & $\begin{array}{c}\text { Box } \\
800 \times 80\end{array}$ \\
\hline 5 & 12.50 & 4.48 & 2.85 & W12 × 190 & $\mathrm{~W} 12 \times 120$ & $\mathrm{~W} 12 \times 210$ & $\begin{array}{c}\text { Box } \\
1100 \times 75\end{array}$ & $\begin{array}{c}\text { Box } \\
700 \times 70\end{array}$ & $\begin{array}{c}\text { Box } \\
800 \times 80\end{array}$ \\
\hline 4 & 13.10 & 4.67 & 3.00 & W12 × 190 & $W 10 \times 100$ & $W 12 \times 210$ & $\begin{array}{c}\text { Box } \\
1100 \times 80\end{array}$ & $\begin{array}{c}\text { Box } \\
700 \times 70\end{array}$ & $\begin{array}{c}\text { Box } \\
800 \times 80\end{array}$ \\
\hline 3 & 13.40 & 4.80 & 3.09 & $W 12 \times 190$ & $\mathrm{~W} 10 \times 100$ & W12 × 152 & $\begin{array}{c}\text { Box } \\
1100 \times 80\end{array}$ & $\begin{array}{c}\text { Box } \\
700 \times 70\end{array}$ & $\begin{array}{c}\text { Box } \\
800 \times 80\end{array}$ \\
\hline 2 & 13.60 & 4.88 & 3.15 & $W 12 \times 190$ & $W 10 \times 100$ & $W 12 \times 120$ & $\begin{array}{c}\text { Box } \\
1100 \times 80\end{array}$ & $\begin{array}{c}\text { Box } \\
700 \times 70\end{array}$ & $\begin{array}{c}\text { Box } \\
800 \times 80\end{array}$ \\
\hline 1 & 14.00 & 4.98 & 3.20 & W12 × 252 & $W 12 \times 120$ & $W 12 \times 120$ & $\begin{array}{c}\text { Box } \\
1100 \times 80\end{array}$ & $\begin{array}{c}\text { Box } \\
700 \times 70\end{array}$ & $\begin{array}{c}\text { Box } \\
800 \times 80\end{array}$ \\
\hline
\end{tabular}

S4R. In the strip method (see Fig. 3, each infill plate was simulated by ten discrete tension-only strips using the truss element T3D2. According to [25] using at least ten strips per panel ensure the accuracy of results. The area of each tension strip $\left(A_{s t}\right)$ and the length of the beam segments $\left(\Delta_{x}\right)$ were calculated respectively by Eqs. (1) and (2). HBEs and VBEs were modeled using the beam element B31.

$$
\begin{gathered}
A_{s t}=\frac{[L \cos (\alpha)+h \sin (\alpha)] t}{n} \\
\Delta_{x}=1 / n[L+h \tan (\alpha)]
\end{gathered}
$$

where $t$ is the thickness of infill plate; $L$ is the bay width of SPSW between the centerline of VBEs; $h$ is the story height; $\alpha$ the angle of tension strips with respect to VBE; and $n$ is the number of strips.

To validate the FE procedure, the 4-story SPSW frame tested by Driver et al. [26] was modeled by both methods and analyzed via pushover analysis. To simulate the actual experimental boundary conditions, all base nodes were restrained against displacements. Gravity loads of $720 \mathrm{kN}$ were applied at the top of each VBE and equal lateral loads were applied at the HBEVBE connections. In the shell element method, a mesh sensitivity analysis was performed regarding various dimensions of shell elements. Based on the obtained results, the mesh dimensions of approximately $100 \times 100 \mathrm{~mm}$ produced accurate results within a reasonable time of computer usage. Therefore, it was taken as the maximum mesh dimensions in the analyses. In reality, the thin infill plates are already in a buckled shape upon mounting. In order to consider the initial imperfection of plates in the nonlinear pushover analysis, an elastic buckling analysis was performed first. Next, the initial imperfections proportional to the lowest Eigen-mode shape of elastic buckling was introduced to the plates. The introduction of plate imperfection is not applicable to the strip models, since infill plates are simulated by tension-only truss elements.

The comparison between experimental and the FE results is shown in Fig. 4, which represents the base shear variation against the $1^{\text {st }}$ story displacement. As reported previously by other researchers [14 16,27], the strip model underestimates the elastic stiffness as well as the ultimate load capacity of the test specimen. Shell element method, however, shows good agreement with the experiment in both elastic and inelastic stages.

\section{Discussion of results}

\subsection{Pushover behavior}

The pushover curves of the 4-, 7-, 10-, and 13-story SPSW models with bay width of $3 \mathrm{~m}$ obtained via the shell element 

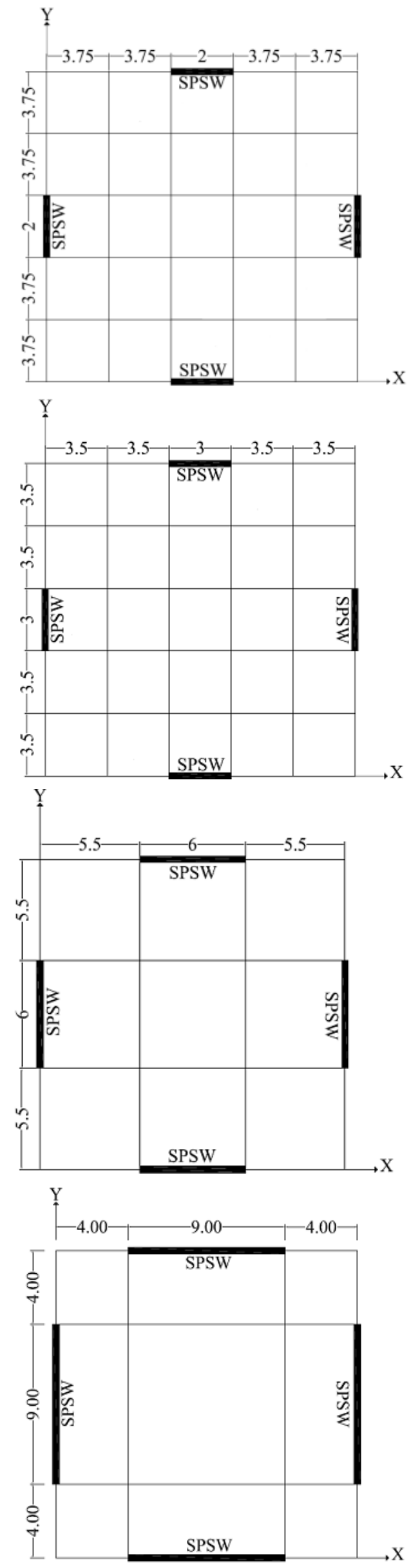

Fig. 1. Typical floor plan of SPSW buildings

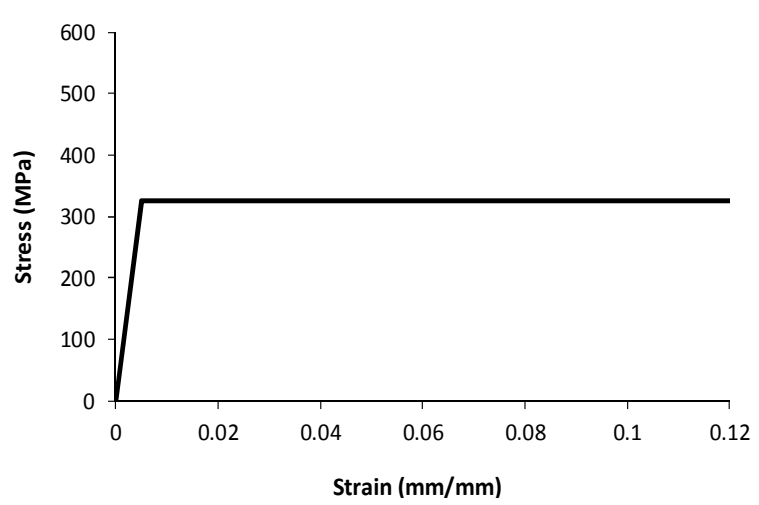

a) Infill plates

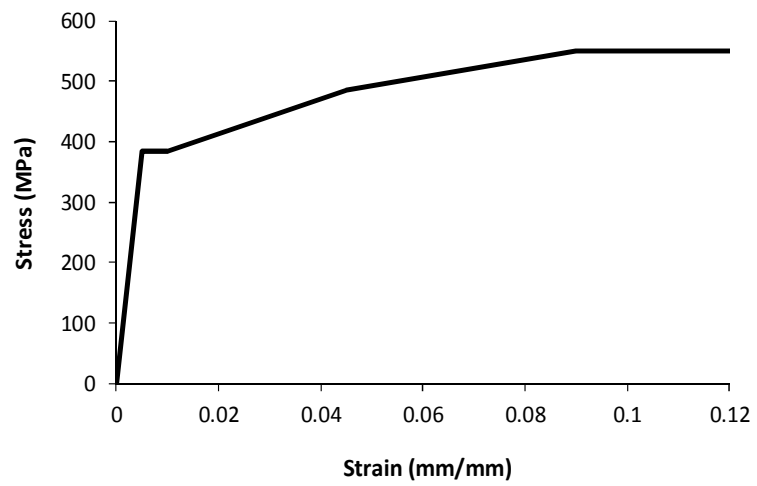

b) Frame members

Fig. 2. Stress-strain characteristics of materials

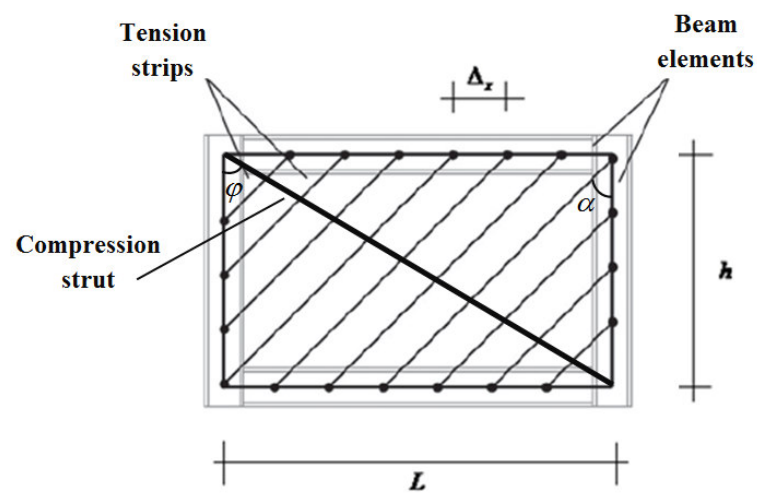

Fig. 3. Strip model

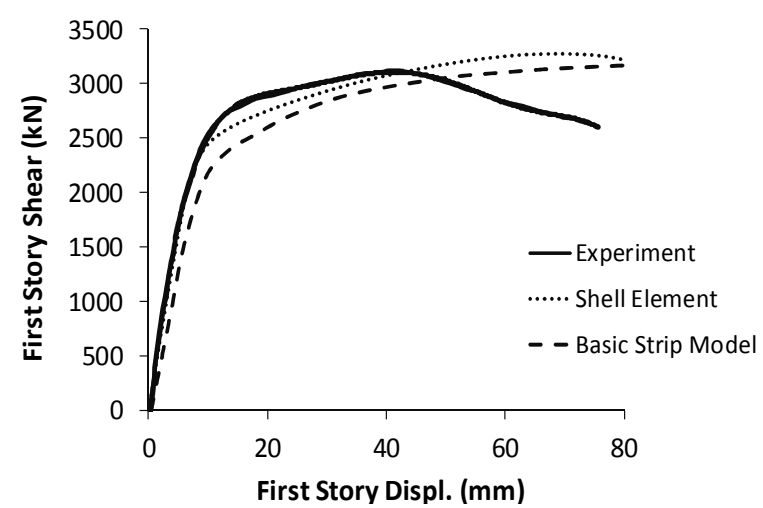

Fig. 4. Verification of FE procedure 
and the strip methods are presented in Fig. 5 Similar to the results obtained for the Driver's 4-story test specimen (see Fig. 4), the strip method underestimates both the initial stiffness and the load carrying capacity in comparison with the shell element method. The differences between the two pushover curves are considerable in the 10- and 13-story frames.

To elaborate on the discrepancy between the results of the two modeling methods, it is required to identify the differences between the modeling techniques employed in each method. The major difference is the type of utilized elements. The effects of element type on the behavior of SPSW frames are discussed next.

\subsubsection{Beam element versus shell element in modeling of frame members}

When beam elements are utilized, the three-dimensional frame members (beams and columns) are approximated with one-dimensional element; and hence it is not possible to model neither the RBS (reduced beam section) connections, nor the panel zones. The typical RBS connection and panel zone utilized in the shell element method is shown in Fig. 6

To approximate the RBS connection in the beam element model, a new beam section with flange width equal to the average value of the original beam flange and the reduced beam flange at the center of RBS $\left(0.5\left(b_{f}+\left(b_{f}-2 c\right)\right)\right)$ is defined. All other parameters are the same as the original beam section. The new beam profile is assigned to the beam at a distance of $\left(0.5 d_{c}+a\right)$ from column centerline having a length of $b$.

Panel zone is the area of the column bounded by the depth of the connecting beam (see Fig. 6). In the shell element model, the continuity plates which are placed in columns against each of the beam flanges make a quite rigid region. In the beam element model, however, modeling of the continuity plates is not possible; and the beam elements cannot represent the true region rigidity. In moment resisting frames, panel zones provide a ductile fuse to dissipate energy. In SPSW frames, however, infill plates are the primary ductile fuse; and most of the inelastic deformations occur within these elements. In the Driver's 4-story test specimen, it was observed that the inelastic deformations in the panel zones were little and these regions remained essentially elastic up to the ultimate capacity [26]. Based on that observation, the panel zones can be modeled as rigid bodies. In commercial software programs such as SAP2000 [21], the panel zones can be easily modeled using the End Offset option. In the ABAQUS finite element software package [24], the desirable rigidity in panel zones can be modeled by assigning an elastic material with a high modulus of elasticity to the frame elements within the connection area (beam elements from the connection node to half the depth of the column and column elements from the connection node to half the depth of the beam on either side).

To investigate the effect of using beam element, first the infill plates were totally removed in both shell element and strip models. It was done in order to eliminate the effect of the truss
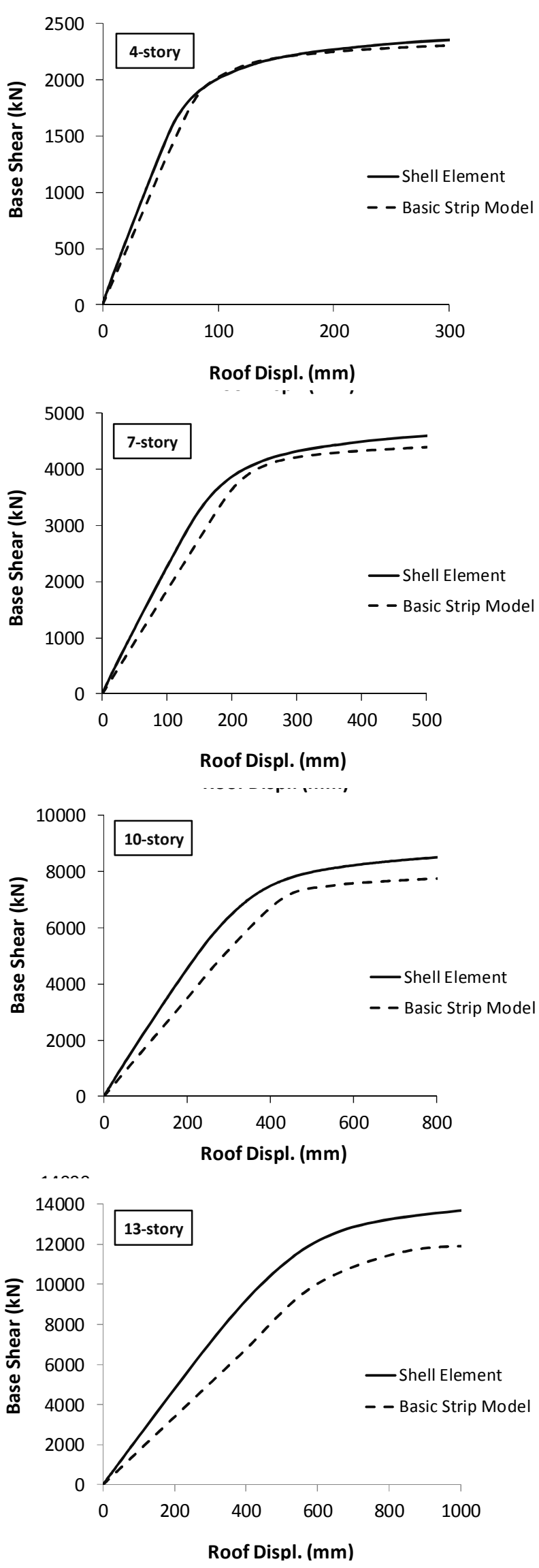

Fig. 5. Pushover curves of SPSW models with bay width of $3 \mathrm{~m}$ via shell element and basic strip methods 


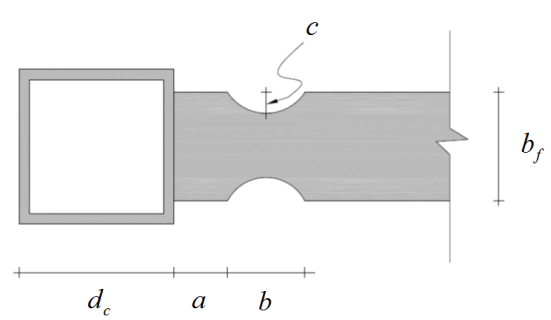

RBS connection

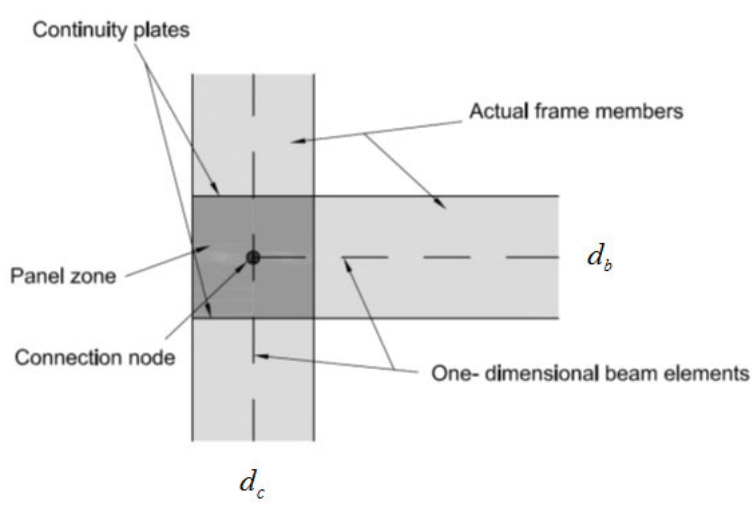

Panel zone

Fig. 6. Typical RBS connection and panel zone

element. The obtained frame-only structures were then analyzed via pushover analysis. Secondly, the RBS connection and panel zone were applied to the beam element model. The pushover curves for the typical 13-story frame-only structure, obtained via both shell and beam element (with and without RBS connections and panel zones) methods are compared in Fig.7 7 The panel zone is hereafter named PZ in the figures. It is observed that the initial stiffness and load carrying capacity of frame modeled by beam element are less than those of the shell element model. On the other hand, when RBS connections and panel zones are employed into the beam element model, the initial stiffness becomes very close to that of the shell element model.

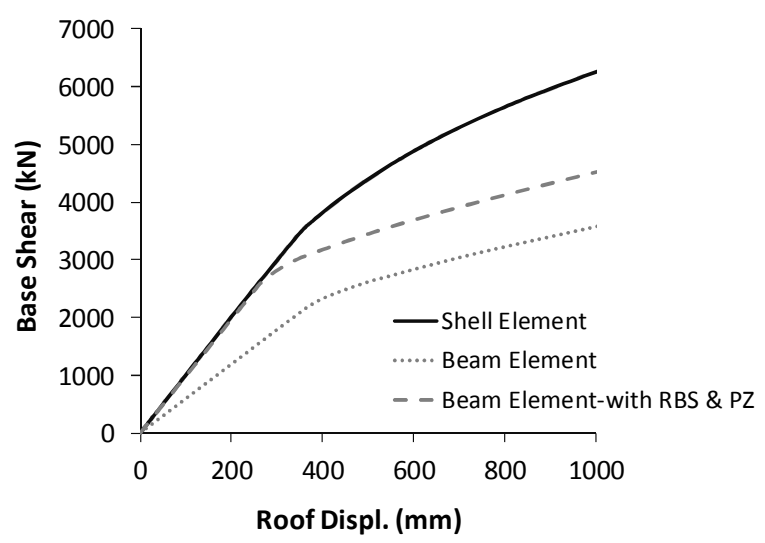

Fig. 7. Pushover curves via shell element and beam element methods, 13story frame-only structure with bay width of $3 \mathrm{~m}$

For a further comparison between the effect of panel zone and RBS connection on the global behavior of frame, the pushover curves of the 7-story frame-only structure which was modeled
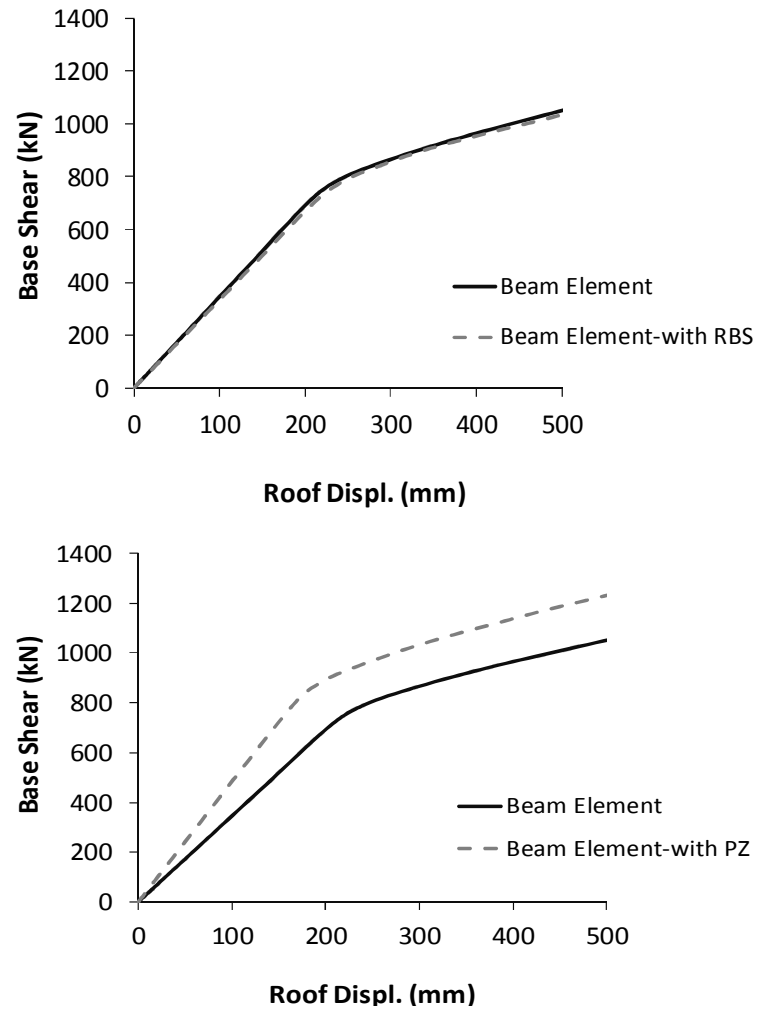

Fig. 8. Pushover curves via beam element method, 7 -story frame-only structure with bay width of $3 \mathrm{~m}$

with the beam element is presented in Fig. 8 One curve is related to the model in which the panel zones and RBS connections were not modeled. The other two curves are related to the models one with panel zones and one with RBS connections. When RBS connections are employed in the frame, its initial stiffness and load carrying capacity are decreased. On the other hand, modeling of rigid panel zones considerably increase the initial stiffness and load carrying capacity of frame. As observed, the effect of RBS connection is much less than that of the panel zone. In the previous studies, it was determined that for the normal flange width reductions employed in the RBS design, the reduction in frame stiffness is in the range of $4 \%$ to 5\% [28]. Therefore, the overall capacity of frame does not considerably get affected by the RBS connections.

In spite of the modifications made to the beam element model, there is still a considerable discrepancy between the overall load capacities in the nonlinear region, see Fig. 7 The nonlinear behavior of frame starts with the yielding of beam elements. In the shell element method, beams' and columns' flanges and webs are separately modeled with their original dimensions. Next, they are meshed into smaller shell elements. The stress-strain calculation is performed individually on each shell element. In the beam element method, however, the total cross section of beams and columns is modeled with a one-dimensional beam element which can only be meshed in one direction. Due to the above differences, the pattern of beam and column yielding is quite different in the two modeling methods. In the shell element method, each shell element can yield individually; whereas in 
the beam element method, the total cross-section yields simultaneously.

It is also well understood that beam elements cannot capture the local buckling of the web and flanges of boundary frame members. However, this phenomenon is not of concern in this study, since the main purpose is to investigate the global behavior of multi-story SPSW frames; and not the local behavior of frame members.

Finally, the limitations which exist in beam elements should also be considered. Beam theory is the one-dimensional approximation of a three-dimensional continuum. The reduction in dimensionality is a direct result of slenderness assumption; that is, the dimensions of the cross-section are small compared to the typical dimension along the axis of the beam. In the beam theory, it is assumed that the member's deformation can be estimated entirely from variables that are functions of position along the beam axis only [24]. ABAQUS offers a wide range of beam elements, including Euler-Bernoulli (slender) and Timoshenko (shear flexible) types. The Euler-Bernoulli elements do not allow for transverse shear deformation and should be used only to model slender beams. In beams made of uniform material, typical dimensions in the cross-section should be less than $1 / 15$ (0.067) of the typical axial distance for transverse shear flexibility to be negligible. On the other hand, the Timoshenko elements allow for transverse shear deformation; and can be used for thick as well as slender beams. In beams made from uniform material, shear flexible beam theory can provide useful results for cross-sectional dimensions up to $1 / 8$ (0.125) of typical axial distance. Beyond this ratio, the approximations that allow the member's behavior to be described solely as a function of axial position no longer provide adequate accuracy [24]. In the present study, beams and columns were modeled with the beam element B31. The element is a Timoshenko element which allows for transverse shear deformations and covers a wider range of slenderness ratio (the ratio of cross-section dimension to typical axial distance) in comparison with the Euler-Bernoulli beam elements.

Using beam elements is well accepted for modeling of moment resisting frames. In SPSW frames, however, large sections are usually required for boundary frame members, especially VBEs. The slenderness ratio of HBEs and VBEs of the 4-, 7-, 10- and 13-strory SPSW frames with different bay widths are given in Tables 5 to 8 , respectively.

As noted in the ABAQUS user's manual [24], the axial dimension of frame members are interpreted as a global dimension, such as distance between supports or wavelength of the highest vibration mode of interest. The given values in Tables 5 to 8 are calculated based on the clear distance between VBEs $\left(L_{\text {clear }}\right)$ for the axial dimension of HBEs; and the clear distance between HBEs $\left(h_{\text {clear }}\right)$ for the axial dimension of VBEs. It should be noted that by employing panel zones into the beam element models, the actual length of frame members, such as those in the shell element models, are simulated.
As shown in Table 8, the slenderness ratio of members in the lower stories of the 13-story SPSW frame is much greater than the maximum slenderness limit specified for beam elements $(0.125)$. That is the reason which reduces the accuracy of the beam element method; and leads to larger discrepancy to those obtained via the shell element method.

Accordingly, two points that are related to the boundary frame members should be considered in the strip model. First, the panel zone should be modeled as an effectively rigid region. The RBS connection should also be modeled in the strip method. However, because of the minor effect of the RBS connection on the global behavior of SPSWs, it can be neglected to reduce the modeling effort. Second, as the slenderness ratio of frame members increases, the accuracy of the strip method reduces. In such cases, modeling with the shell element method should be preferred.

\subsubsection{Truss element versus shell element in modeling of infill plates}

The basic assumption in the strip model is that the shear resistance of the infill plate only consists of the post-buckling strength, attained by the development of inclined tension field. The shear resistance of infill plate prior to the buckling is neglected on the assumption that the infill plate is so thin that it buckles under low lateral loads. Based on these two assumptions, the infill plate is represented by tension-only strips in the direction of tension field action (see Fig. 3).

In low-rise SPSW structures and SPSWs with large bay width, very thin infill plates with small buckling strengths are utilized; and thus compressive strength of infill plates can be neglected. In high-rise SPSW structures and SPSWs with relatively small bay width, on the other hand, the compressive strength of infill plates is considerable due to the thicker design plates. The buckling strength $\left(\tau_{c r}\right)$ of the infill plates of the 4-, 7-, 10- and 13-story SPSW frames with different bay widths are given in Tables 9 to 12, respectively. The given values are calculated by the classical formula (Eq. (3)); based on the assumptions that the plate is under pure shear, and that all four edges are simply supported.

$$
\begin{gathered}
\tau_{c r}=\frac{k \pi^{2} E}{12\left(1-v^{2}\right)}\left(\frac{t}{b}\right)^{2} \\
k=5.35+\frac{4}{\varphi^{2}}, \varphi>1 \\
k=4+\frac{5.35}{\varphi^{2}}, \varphi<1
\end{gathered}
$$

where $E$ is the modulus of elasticity; $v$ is the Poisson's ratio; and $k$ is the buckling coefficient which is defined as the function of the aspect ratio of the plate $\left(\varphi=\frac{a}{b}\right), a, b$ and $t$ are respectively the length, the width, and the thickness of plate.To account for the pre-buckling strength of infill plates, it has been suggested to utilize a compression strut in the strip method [27]. The compression strut is a truss element which extends from corner to 
Tab. 5. Slenderness ratio of HBEs and VBEs, 4-story SPSW frames

\begin{tabular}{ccccccccc}
\hline \multicolumn{9}{c}{$d_{b} / L_{\text {clear }}$} \\
\hline \multirow{2}{*}{ Level } & Width - & Width - & Width - & Width - & Width - & Width - & Width - & Width - \\
& $\mathbf{2 ~} \mathbf{~}$ & $\mathbf{3 ~ \mathbf { ~ }}$ & $\mathbf{6 ~} \mathbf{~}$ & $\mathbf{9 ~ \mathbf { ~ }}$ & $\mathbf{2 ~ \mathbf { ~ }}$ & $\mathbf{3 ~ \mathbf { ~ }}$ & $\mathbf{6 ~ \mathbf { ~ }}$ & $\mathbf{9} \mathbf{~ m}$ \\
\hline $\mathbf{4}$ & 0.139 & 0.082 & 0.063 & 0.053 & 0.105 & 0.089 & 0.108 & 0.142 \\
\hline $\mathbf{3}$ & 0.181 & 0.082 & 0.061 & 0.050 & 0.121 & 0.089 & 0.122 & 0.172 \\
\hline $\mathbf{2}$ & 0.187 & 0.084 & 0.058 & 0.046 & 0.136 & 0.104 & 0.122 & 0.170 \\
\hline $\mathbf{1}$ & 0.187 & 0.084 & 0.058 & 0.041 & 0.130 & 0.100 & 0.116 & 0.161 \\
\hline
\end{tabular}

Tab. 6. Slenderness ratio of HBEs and VBEs, 7-story SPSW frames

\begin{tabular}{|c|c|c|c|c|c|c|c|c|}
\hline \multirow[b]{2}{*}{ Level } & \multicolumn{4}{|c|}{$d_{b} / L_{\text {clear }}$} & \multicolumn{4}{|c|}{$d_{c} / h_{\text {clear }}$} \\
\hline & $\begin{array}{c}\text { Width - } \\
2 \mathrm{~m}\end{array}$ & $\begin{array}{c}\text { Width - } \\
3 \mathrm{~m}\end{array}$ & $\begin{array}{l}\text { Width - } \\
6 \mathrm{~m}\end{array}$ & $\begin{array}{c}\text { Width - } \\
9 \mathrm{~m}\end{array}$ & $\begin{array}{l}\text { Width - } \\
2 \mathrm{~m}\end{array}$ & $\begin{array}{c}\text { Width - } \\
3 \mathrm{~m}\end{array}$ & $\begin{array}{l}\text { Width - } \\
6 \mathrm{~m}\end{array}$ & $\begin{array}{c}\text { Width - } \\
9 \mathrm{~m}\end{array}$ \\
\hline 7 & 0.135 & 0.082 & 0.065 & 0.055 & 0.104 & 0.089 & 0.108 & 0.159 \\
\hline 6 & 0.147 & 0.084 & 0.062 & 0.053 & 0.135 & 0.104 & 0.123 & 0.174 \\
\hline 5 & 0.193 & 0.106 & 0.063 & 0.053 & 0.151 & 0.135 & 0.138 & 0.189 \\
\hline 4 & 0.200 & 0.106 & 0.060 & 0.048 & 0.166 & 0.135 & 0.153 & 0.188 \\
\hline 3 & 0.207 & 0.110 & 0.060 & 0.048 & 0.181 & 0.150 & 0.152 & 0.186 \\
\hline 2 & 0.214 & 0.110 & 0.049 & 0.042 & 0.196 & 0.151 & 0.150 & 0.184 \\
\hline 1 & 0.214 & 0.113 & 0.049 & 0.038 & 0.188 & 0.145 & 0.144 & 0.174 \\
\hline
\end{tabular}

Tab. 7. Slenderness ratio of HBEs and VBEs, 10-story SPSW frames

\begin{tabular}{|c|c|c|c|c|c|c|}
\hline \multirow[b]{2}{*}{ Level } & \multicolumn{3}{|c|}{$d_{b} / L_{\text {clear }}$} & \multicolumn{3}{|c|}{$d_{c} / h_{\text {clear }}$} \\
\hline & Width - $3 \mathrm{~m}$ & Width - $6 \mathrm{~m}$ & Width - 9 m & Width - $3 \mathrm{~m}$ & Width - $6 \mathrm{~m}$ & Width - $9 \mathrm{~m}$ \\
\hline 10 & 0.086 & 0.065 & 0.055 & 0.105 & 0.108 & 0.159 \\
\hline 9 & 0.108 & 0.066 & 0.055 & 0.135 & 0.139 & 0.191 \\
\hline 8 & 0.112 & 0.067 & 0.053 & 0.166 & 0.169 & 0.206 \\
\hline 7 & 0.123 & 0.062 & 0.054 & 0.196 & 0.169 & 0.238 \\
\hline 6 & 0.123 & 0.063 & 0.054 & 0.198 & 0.184 & 0.236 \\
\hline 5 & 0.155 & 0.061 & 0.047 & 0.231 & 0.183 & 0.234 \\
\hline 4 & 0.155 & 0.061 & 0.047 & 0.231 & 0.182 & 0.234 \\
\hline 3 & 0.158 & 0.051 & 0.047 & 0.231 & 0.180 & 0.232 \\
\hline 2 & 0.158 & 0.051 & 0.041 & 0.232 & 0.181 & 0.229 \\
\hline 1 & 0.163 & 0.052 & 0.039 & 0.219 & 0.173 & 0.218 \\
\hline
\end{tabular}

Tab. 8. Slenderness ratio of HBEs and VBEs, 13-story SPSW frames

\begin{tabular}{ccccccc}
\hline & \multicolumn{3}{c}{$d_{b} / L_{\text {clear }}$} & & \multicolumn{3}{c}{$d_{c} / h_{\text {clear }}$} \\
\hline Level & Width -3 $\mathbf{m}$ & Width -6 $\mathbf{~}$ & Width - 9 $\mathbf{m}$ & Width - 3 $\mathbf{m}$ & Width - 6 $\mathbf{m}$ & Width -9 $\mathbf{m}$ \\
\hline $\mathbf{1 3}$ & 0.088 & 0.065 & 0.056 & 0.120 & 0.124 & 0.160 \\
\hline $\mathbf{1 2}$ & 0.115 & 0.067 & 0.057 & 0.166 & 0.155 & 0.192 \\
\hline $\mathbf{1 1}$ & 0.123 & 0.067 & 0.057 & 0.211 & 0.170 & 0.223 \\
\hline $\mathbf{1 0}$ & 0.132 & 0.068 & 0.054 & 0.242 & 0.200 & 0.238 \\
\hline $\mathbf{9}$ & 0.138 & 0.065 & 0.054 & 0.275 & 0.200 & 0.253 \\
\hline $\mathbf{8}$ & 0.169 & 0.066 & 0.052 & 0.277 & 0.215 & 0.252 \\
\hline $\mathbf{7}$ & 0.178 & 0.063 & 0.052 & 0.308 & 0.214 & 0.251 \\
\hline $\mathbf{6}$ & 0.178 & 0.063 & 0.048 & 0.309 & 0.214 & 0.249 \\
\hline $\mathbf{5}$ & 0.193 & 0.063 & 0.046 & 0.340 & 0.213 & 0.248 \\
\hline $\mathbf{4}$ & 0.193 & 0.053 & 0.046 & 0.340 & 0.211 & 0.247 \\
\hline $\mathbf{3}$ & 0.193 & 0.053 & 0.042 & 0.340 & 0.211 & 0.245 \\
$\mathbf{2}$ & 0.193 & 0.053 & 0.041 & 0.341 & 0.213 & 0.245 \\
$\mathbf{1}$ & 0.206 & 0.063 & 0.041 & 0.323 & 0.204 & 0.233 \\
\hline
\end{tabular}


corner of each infill plate in the opposite diagonal direction to that of the tension strips (see Fig. 3). Assuming that the whole infill plate contributes to the compressive resistance, the area of the strut is calculated based on the equivalent brace method using Eq. (4).

$$
A=\frac{t . L \cdot \sin ^{2} 2 \alpha}{2 \sin \phi \cdot \sin 2 \phi}
$$

where $\phi$ is the angle of compression strut with respect to VBE and other terms have been defined previously.

The capacity of the compression strut should be limited to simulate the sudden buckling of plate. Based on the sensitivity analysis in ref. [27] for the strip model of the Driver's 4story test specimen, a value of 0.08 of the infill plate yield stress $\left(F_{y P L}\right)$ was proposed for the limiting stress of the compression strut $\left(F_{y C S}\right)$ since it resulted in the best fit of the pushover curve of the strip model to that of the experiment.
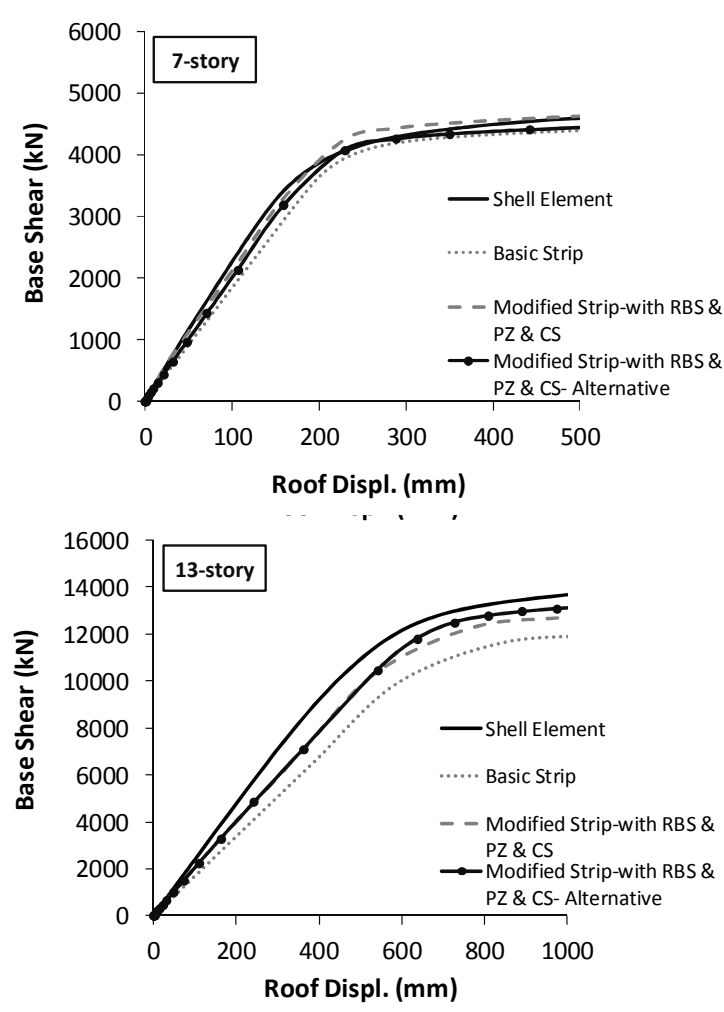

Fig. 9. Pushover curves via shell element and strip methods, models with bay width of $3 \mathrm{~m}$

In the current study, the compression strut was applied to the 7-, and 13-story SPSW frames with $3 \mathrm{~m}$ bay width. The area of the struts was calculated via Eq. (4) and the limiting stress of the struts was set to $26 \mathrm{MPa}(0.08 * 325 \mathrm{MPa})$. The obtained pushover curves with those of the shell element and the basic strip models are presented in Fig. 9. The "compression strut" is called CS in the figure. Results show that by applying the compression strut, the load carrying capacity of the 7-story SPSW frame is overestimated in comparison with the corresponding shell element model. Further investigations in ref. [27] on the pushover behavior of the strip models of other test specimens also showed that setting $F_{y C S}$ to $0.08 F_{y P L}$ does not provide acceptable results in various SPSW frames.

The buckling strength of the infill plate $\left(\tau_{c r}\right)$ may be used as an alternative value for the limiting stress of the compression strut $\left(F_{y C S}\right)$. Assuming that infill plates are under pure shear, the principal tension and compression stresses at the instant of buckling are equal to $\tau_{c r}$ at an angle of $45^{\circ}$. Although the orientaion angle of the compression strut does not neccesserily match $45^{\circ}$, the stress value in the orientaion of the strut can be approximately estimated to be equal to the plate buckling strength.

In the 7- and 13-story frames, the limiting stress of the compression struts was set to those values presented in Tables 10 and 12 in width $-3 \mathrm{~m}$, respectively. The obtained pushover curves are also presented in Fig. 9, named as "Modified Strip-with RBS \& PZ \& CS- Alternative".

As shown, when the value of $F_{y C S}$ is set equal to the buckling strength of the infill plate $\left(\tau_{c r}\right)$, there is no overestimation, neither in the initial stiffness nor in the load capacity. In the $13-$ story SPSW frame, the load capacity is improved in comparison to that obtained when $F_{y C S}$ was set to $0.08 F_{y P L}$.

As seen in Fig. 9, there are still some discrepancies between the results of the two modeling methods especially for the 13story SPSW frame. The discrepancies mainly arise from using the beam element for modeling bulky sections of the boundary frame members (see Fig. 7).

\subsection{The accuracy of strip model regarding the bay width of SPSW frame}

The SPSW frames with bay widths other than $3 \mathrm{~m}$ were modeled via the basic strip and the modified strip method (with RBS \& PZ \& CS- Alternative). The obtained pushover curves along with those of models with $3 \mathrm{~m}$ width are presented in Fig. 10 . Results show that the discrapancy between the two pushover curves decreases with the increase in the bay width of SPSWs.

According to the explanations presented in the AISC-341 [18], modeling a SPSW with strip model is reasonably accurate for panel aspect ratios that exceed 0.8 . In the present study, a constant typical story height of $3.6 \mathrm{~m}$ was presumed in all frames. Therefore, the panel aspect ratio of SPSW frames with bay widths of 2, 3, 6 and $9 \mathrm{~m}$ are $0.56,0.83,1.67$ and 2.5, respectively. Results presented in Fig. 10 show that the accuracy of the strip model is also affected by the number of story levels. In the 4- and 7-story SPSW frames, the discrepancy between the two pushover curves is considerable for the models with $2 \mathrm{~m}$ width (panel aspect ratio of 0.56 ). In all other widths, the stiffness and load carrying capacity do not change consideably when modifications are made to the basic strip model. In the 10- and 13-story SPSW frames, however, the discrepancy between the two pushover curves of models with $3 \mathrm{~m}$ width (panel aspect ratio of 0.83 ) is considerable.

In the 10- and 13-story SPSW models with $3 \mathrm{~m}$ width, large design sections are required for VBEs, especially in the lower stories (see Tables 3 and 4). On the other hand, Tables 11 and 
Tab. 9. The buckling strength of infill plates, 4-story SPSW frames

\begin{tabular}{cccccc}
\hline & Level & $\mathbf{1}$ & $\mathbf{2}$ & $\mathbf{3}$ & $\mathbf{4}$ \\
\hline \multirow{4}{*}{$\tau_{c r}(\mathrm{MPa})$} & Width -2 $\mathbf{m}$ & 13.40 & 10.64 & 5.87 & 1.68 \\
\cline { 2 - 6 } & Width -3 m & 1.99 & 1.60 & 0.91 & 0.29 \\
\cline { 2 - 6 } & Width -6 m & 0.23 & 0.19 & 0.12 & 0.04 \\
\cline { 2 - 6 } & Width -9 m & 0.09 & 0.08 & 0.05 & 0.02 \\
\hline
\end{tabular}

Tab. 10. Table 10 . The buckling strength of infill plates, 7-story SPSW frames

\begin{tabular}{|c|c|c|c|c|c|c|c|c|}
\hline \multicolumn{2}{|c|}{ Level } & 1 & 2 & 3 & 4 & 5 & 6 & 7 \\
\hline \multirow{4}{*}{$\tau_{c r}(M P a)$} & Width-2 m & 76.84 & 66.46 & 49.71 & 32.74 & 19.69 & 9.07 & 2.03 \\
\hline & Width $-3 \mathrm{~m}$ & 7.60 & 6.79 & 5.89 & 4.35 & 2.83 & 1.33 & 0.35 \\
\hline & Width $-6 \mathrm{~m}$ & 0.73 & 0.7 & 0.62 & 0.47 & 0.32 & 0.16 & 0.05 \\
\hline & Width $-9 \mathrm{~m}$ & 0.26 & 0.27 & 0.24 & 0.19 & 0.13 & 0.07 & 0.02 \\
\hline
\end{tabular}

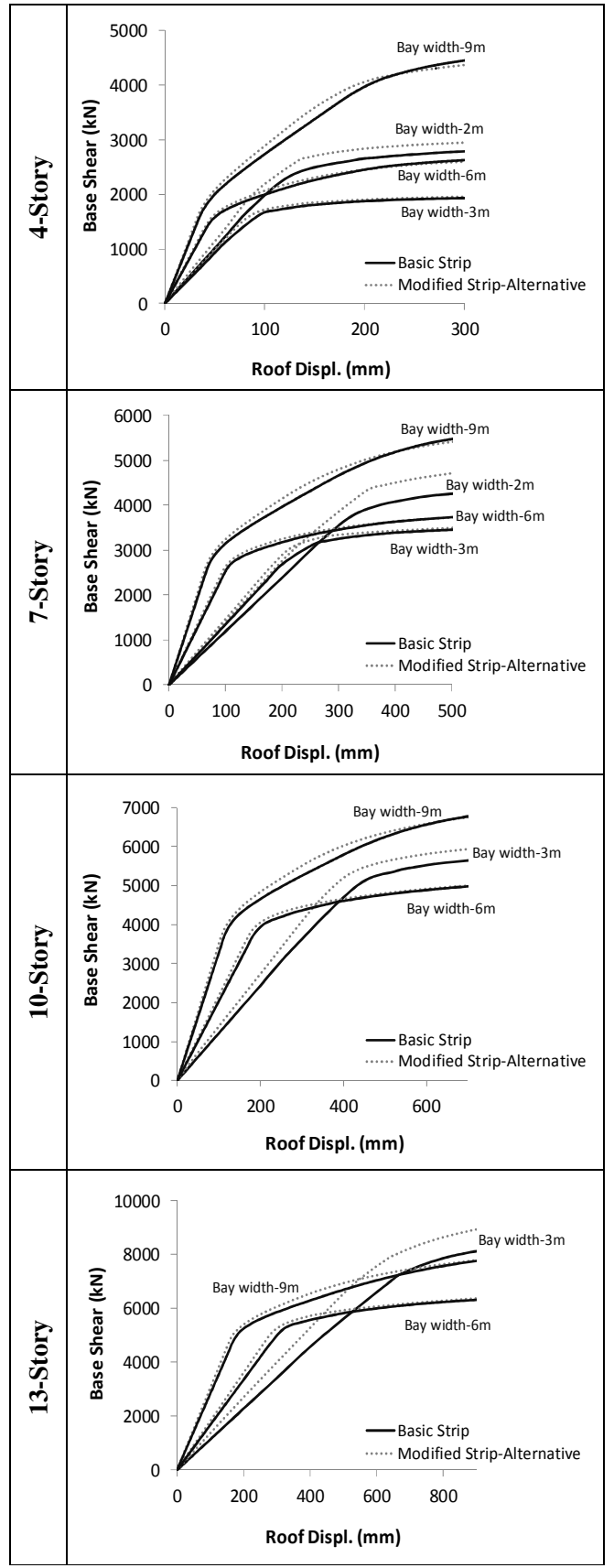

Fig. 10. Pushover curves of SPSW models with different bay widths

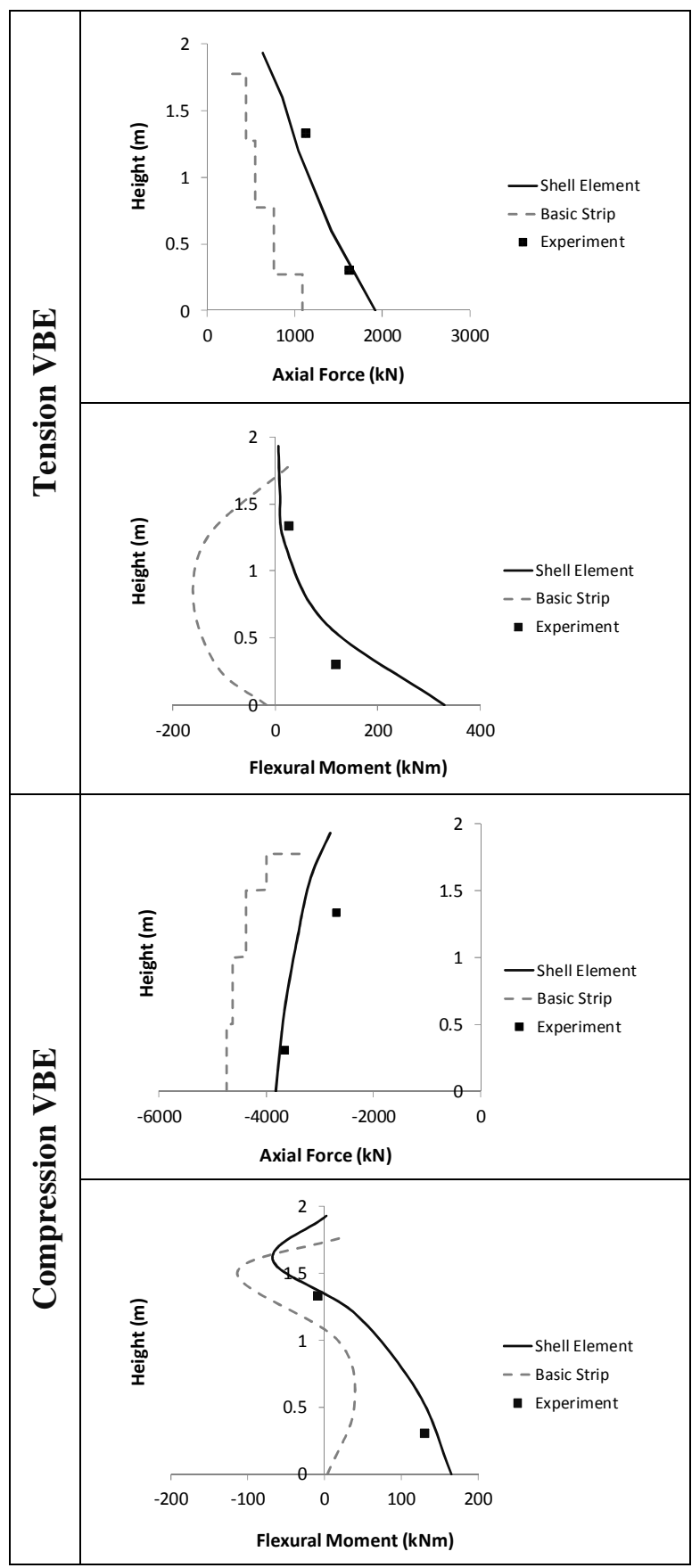

Fig. 11. Axial force and flexural moment demands, Driver's test specimen$1^{s t}$ story VBEs 
Tab. 11. The buckling strength of infill plates, 10-story SPSW frames

\begin{tabular}{|c|c|c|c|c|c|c|c|c|c|c|c|}
\hline & evel & 1 & 2 & 3 & 4 & 5 & 6 & 7 & 8 & 9 & 10 \\
\hline \multirow[b]{2}{*}{$\tau_{c r}(M P a)$} & Width - 3 m & 21.99 & 21.13 & 19.70 & 17.44 & 14.91 & 10.42 & 7.38 & 4.10 & 1.76 & 0.43 \\
\hline & Width - 6 m & 1.53 & 1.57 & 1.44 & 1.34 & 1.15 & 0.92 & 0.65 & 0.42 & 0.20 & 0.05 \\
\hline
\end{tabular}

Tab. 12. The buckling strength of infill plates, 13-story SPSW frames

\begin{tabular}{|c|c|c|c|c|c|c|c|c|c|c|c|c|c|}
\hline Level & 1 & 2 & 3 & 4 & 5 & 6 & 7 & 8 & 9 & 10 & 11 & 12 & 13 \\
\hline Width - 3 m & 67.97 & 65.55 & 63.54 & 60.72 & 55.29 & 40.92 & 35.26 & 24.49 & 18.78 & 11.43 & 6.01 & 2.36 & 0.51 \\
\hline$\tau_{c r}(M P a)$ Width-6 m & 2.81 & 2.87 & 2.75 & 2.60 & 2.42 & 2.19 & 1.89 & 1.54 & 1.18 & 0.83 & 0.48 & 0.23 & 0.06 \\
\hline Width - 9 m & 1.00 & 1.06 & 1.02 & 0.97 & 0.88 & 0.80 & 0.69 & 0.57 & 0.44 & 0.32 & 0.20 & 0.10 & 0.03 \\
\hline
\end{tabular}

12 show that the buckling strength of the infill plates of the 10and 13-story SPSW frames with $3 \mathrm{~m}$ width is considerable in the lower stories. Accordingly, the employing of panel zones and compression struts in the basic strip model of these two SPSW frames increase the stiffness and load capacity considerably.

\subsection{Internal forces of VBEs}

According to the specifications of AISC-341 [18] the nonlinear pushover analysis is recognized for the determination of the design forces of VBEs per the capacity design requirements. In this section, the accuracy of various modeling methods regarding the VBEs' force demands is investigated.

For the Driver's 4-story test specimen, the axial force and flexural moment demands along the height of the $1^{\text {st }}$ story VBEs are shown in Fig. 11. For comparison purposes, the results of both shell element and basic strip methods are presented along with those derived from strain measurements during the test [27]. As shown in Fig. 11, the results of the shell element method show better agreement with those of the experiment.

For the present studied frames, the variation of the axial and shear forces, as well as the flexural moments along the height of the compression VBE of the 7-story and tension VBE of the 13story SPSW frames with bay width of $3 \mathrm{~m}$, are presented respectively in Figs. 12 and 13 as examples. The values are obtained via the shell element, the basic strip and the modified strip (with RBS \& PZ \& CS-Alternative) methods at the ultimate state.

According to the obtained results, the use of modified strip method overestimates the axial force of VBEs. The discrepancies between the axial forces obtained via the two strip methods with that of the shell element method at the base of the VBEs are given in Table 13

The shear force of VBEs via the modified strip method is slightly improved. Regarding the flexural moment of VBEs, results show that in the lower stories of the 7-story and in the most upper stories of the 13-story SPSW frames, the flexural moment via the two strip methods are quite similar. In other stories, however, the results of the basic strip method are in better conformity with those of the shell element method.

The horizontal and vertical components of the inclined forces induced by the tension strips and the compression strut on the boundary frame members are presented in Fig. 14. As shown, in both tension and compression VBEs, the vertical component of the compression strut force is in the same direction as those vertical force components induced by the tension strips. Therefore, in the modified strip method, the axial force of both tension and compression VBEs increases in comparison with the basic strip method. Nevertheless, the basic strip method is still more accurate in predicting the VBEs' internal forces than the modified strip method. Therefore, in design of VBEs, it is recommended to use the basic strip method rather than the modified strip method.

\subsection{Distribution of story shear between infill plates and VBEs}

In the conventional design of SPSWs, it is assumed that the full story shear is resisted by infill plates. HBEs and VBEs are then designed according to the thickness of plates. Following this approach, the shear strength provided by the boundary frame moment resisting action is neglected; resulting in thicker plates and larger HBEs/VBEs sections. Upon the completion of the preliminary design of a SPSW structure, a pushover analysis is performed to determine the portion of story shear carried by VBEs. Subsequently, it is possible to revise the infill plate thickness as well as the design sections of frame members [25].

For the typical stories of the 4-, and 13-story SPSW models with $3 \mathrm{~m}$ width, the total story shear with the shear contribution of infill plates and frames are shown in Fig. 15. The presented values are related to the ultimate state. Results show that the story shear obtained via the basic strip model is smaller than the corresponding shell element model. However, the shear contribution of infill plates is increased in the basic strip model, and in turn, the shear contribution of frame is decreased. In the $4^{\text {th }}$ story of the 4-story SPSW frame, the shear contribution of infill plate is so large that the shear strength of frame members acts in the same direction of the external lateral loads to maintain equilibrium.

Fig. 16 presents the dimensional proportions of frame members and infill plate in the strip and shell element modeling methods. Due to the one-dimensional approximation of frame members in the strip method, the area of the strips is calculated ac- 
Tab. 13. The discrepancies in the axial force at the base of the VBEs

\begin{tabular}{ccc}
\hline \multirow{2}{*}{ SPSW Frame } & \multicolumn{2}{c}{ Difference (\%) } \\
\cline { 2 - 3 } & Basic strip method & Modified strip method \\
\hline 7 - story & 5.50 & 6.60 \\
\hline 13 - story & -2.20 & 17.80 \\
\hline
\end{tabular}

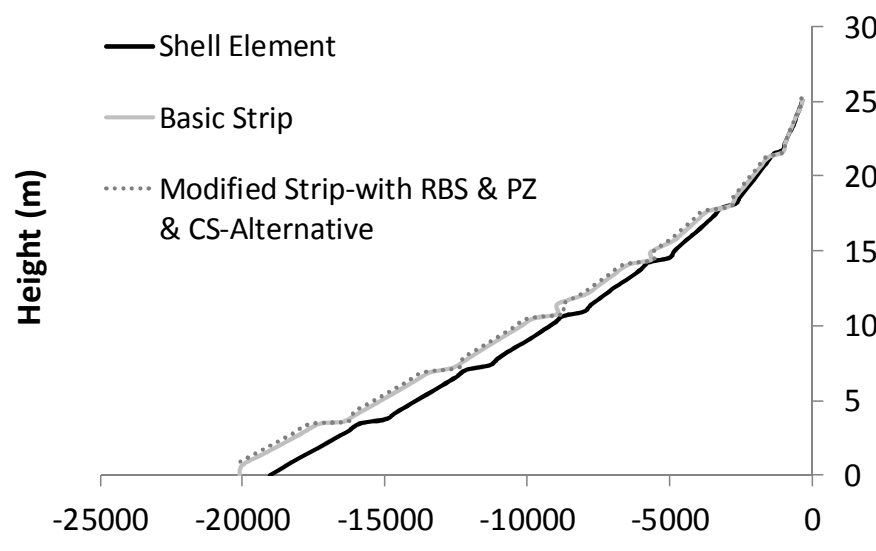

Axial Force (kN)
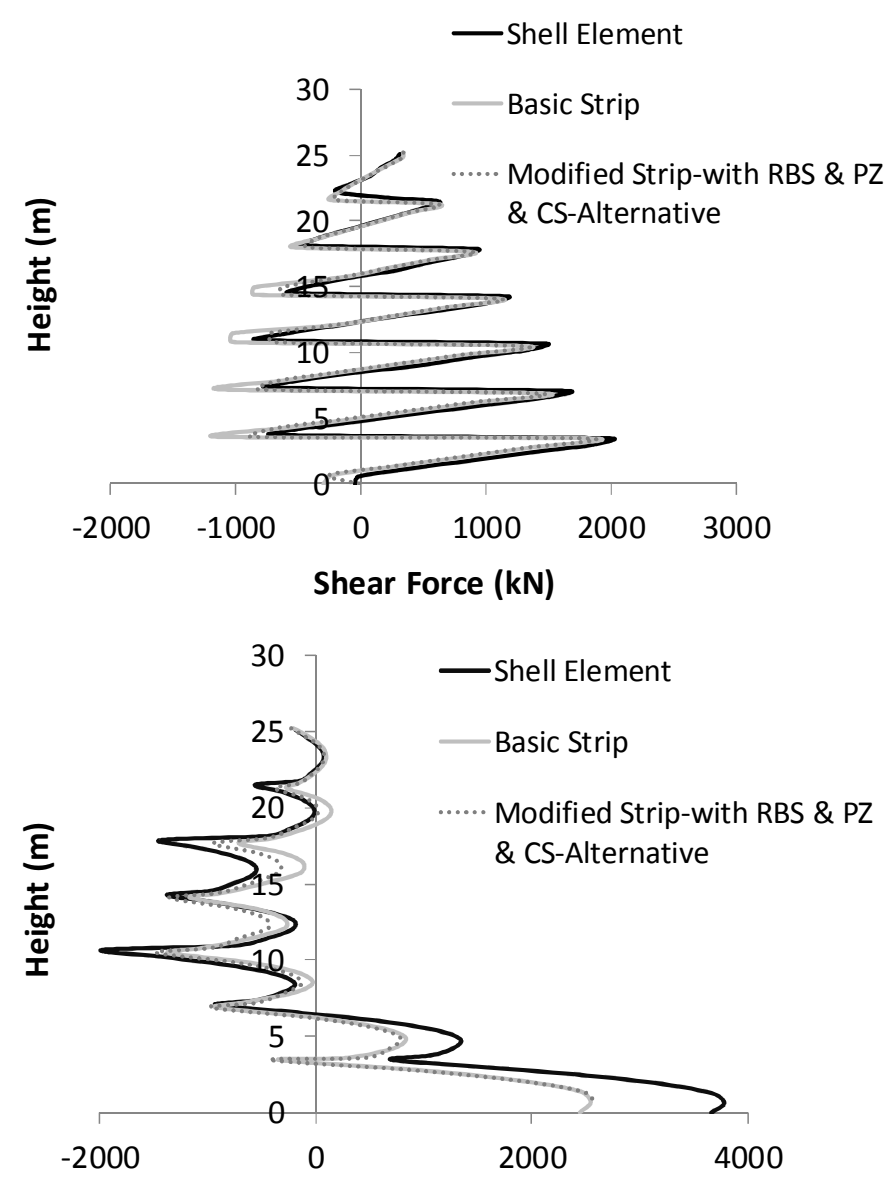

Flexural Moment (kNm)

Fig. 12. Axial, shear and flexural moment demands, 7-story SPSW framecompression VBE

30

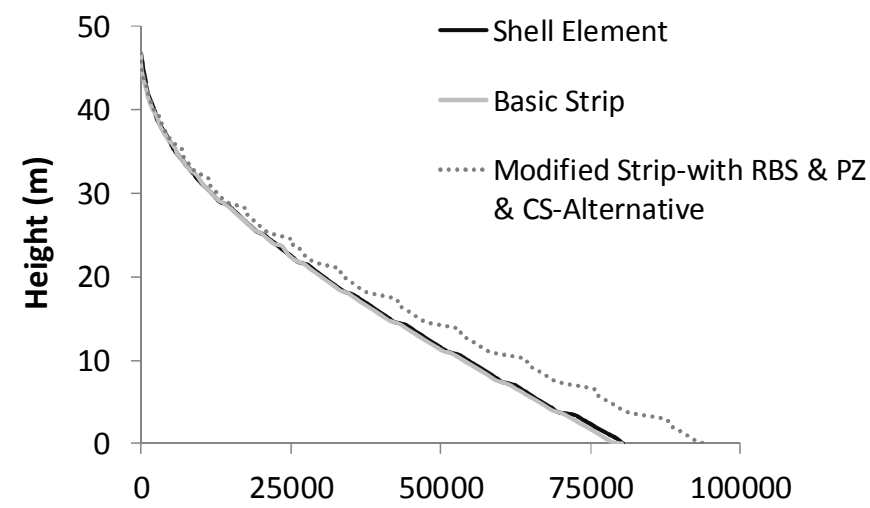

Axial Force (kN)

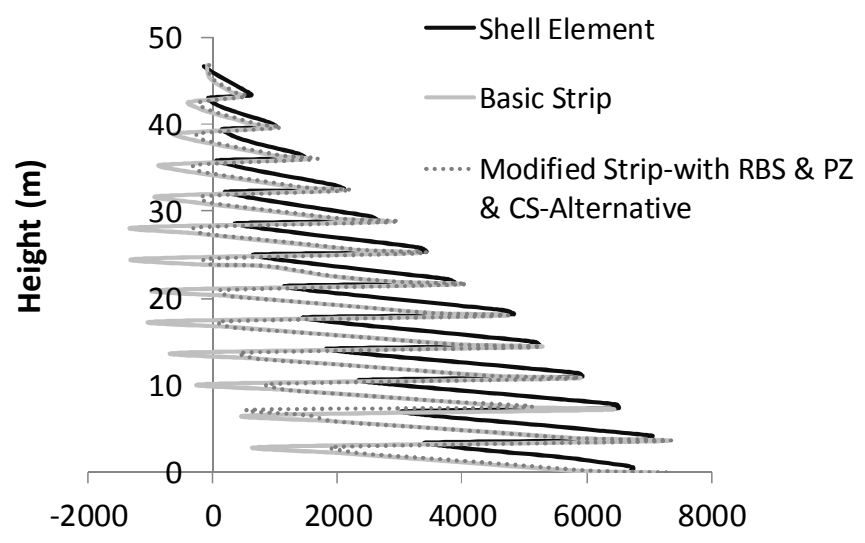

Shear Force (kN)

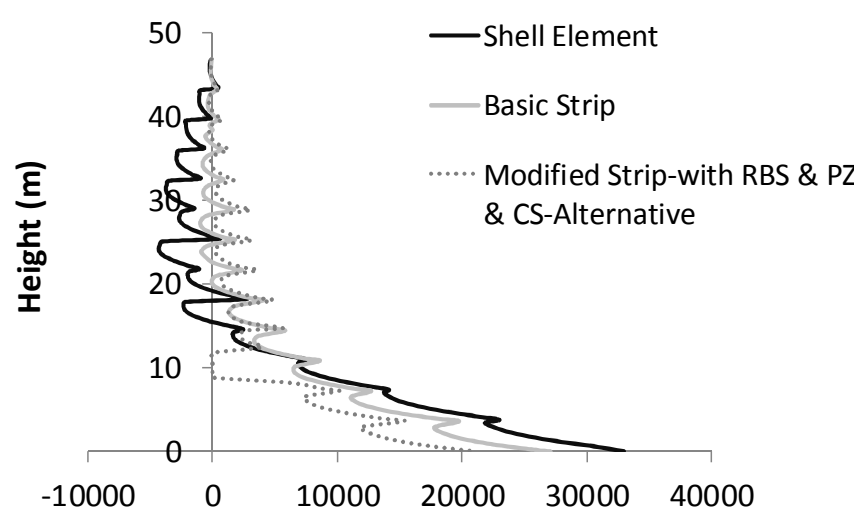

Flexural Moment (kNm)

Fig. 13. Axial, shear and flexural moment demands, 13-story SPSW frametension VBE 


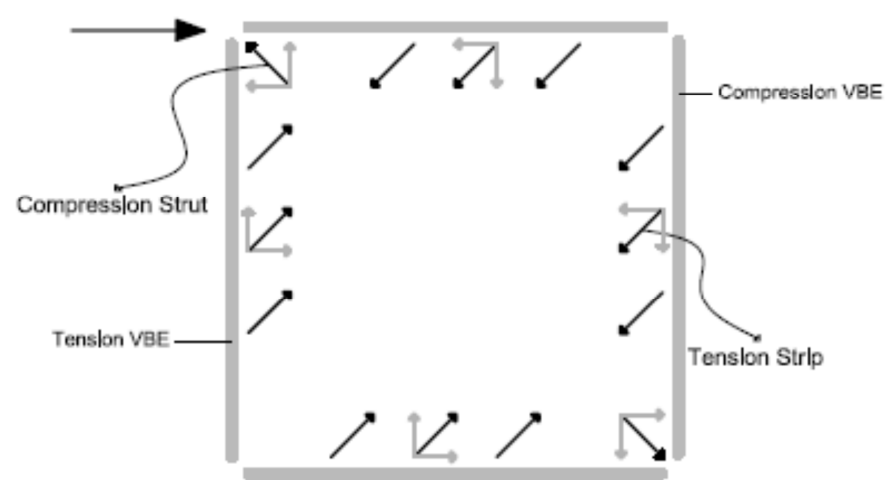

Fig. 14. Force components induced by the tension strips and the compression strut on the boundary frame members

cording to the distance between the centerline of frame members (see Eq. (1)). Regarding the actual dimension of frame members, the effective area of the infill plate perpendicular to the direction of the tension field is smaller than those considered in the strip model. For the typical stories presented in Fig. 15 , the effective area of the infill plates in each of the two modeling methods is given in Tables 14 and 15

As the area of the infill plate increases, more shear is absorbed by them; and in turn, the shear contribution of frame members reduces. In the modified strip method, the shear contribution of the infill plates is even greater due to the additional area provided by the compression strut.

According to the above results, both the basic and the modified strip methods provide conservative design of SPSW frames since they result in greater shear contribution of infill plates. Greater shear yields to thicker infill plates, which in turn, result in larger design sections of boundary frame members.

\section{Conclusions}

In this study, fourteen steel plate shear wall models with story levels of 4, 7, 10 and 13 in different bay widths of 2, 3, 6 and $9 \mathrm{~m}$ were designed according to the rules and specifications of AISC-341 and AISC-360 codes. The SPSW frames were modeled via the two available modeling methods, namely as the shell element model and the strip model methods. The frames were analyzed via the nonlinear pushover analysis. Based on the results obtained in this research, the following points were concluded:

- The strip model underestimates both the initial stiffness and the load carrying capacity of SPSW structures in comparison to the shell element method. In high-rise SPSW frames and SPSWs with relatively small bay width, the discrepancy between the results of the two methods becomes considerable.

- In spite of the previous researches which had focused on the truss elements as the main source of errors, the beam elements employed in modeling of the boundary frame members showed considerable effects on the response of SPSW structures.
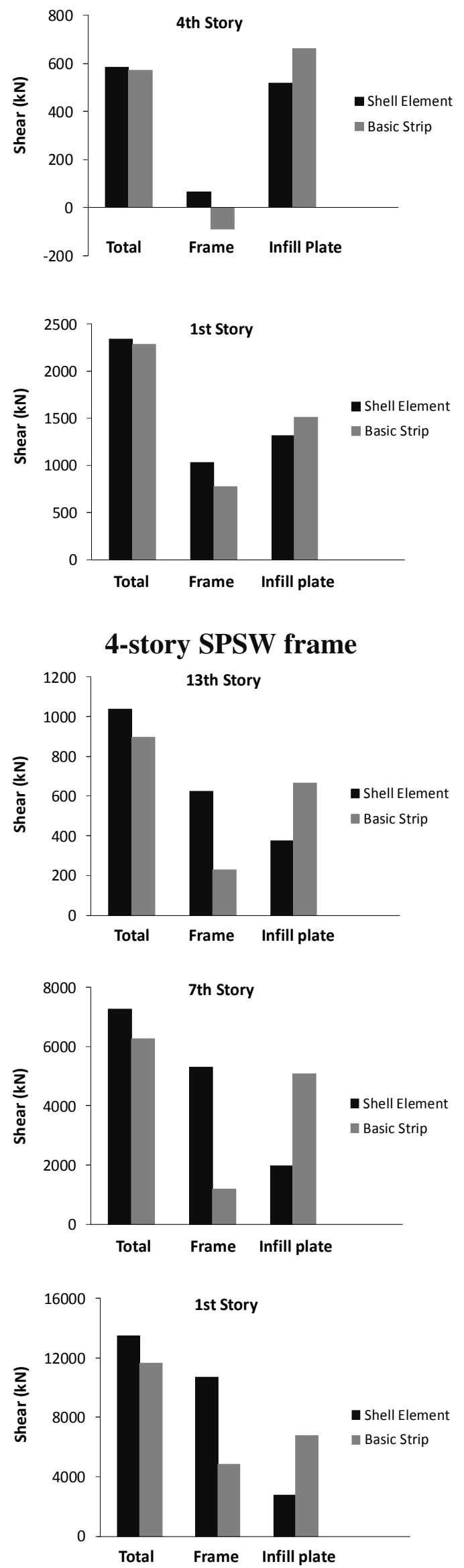

\section{3-story SPSW frame}

Fig. 15. The story shear distribution, models with bay width of $3 \mathrm{~m}$ 
Tab. 14. The effective area of the infill plates, 4-story SPSW frame with bay width of $3 \mathrm{~m}$

\begin{tabular}{cccc}
\hline \multirow{2}{*}{ Level } & \multicolumn{2}{c}{ Plate area perpendicular to the direction of tension field $\left(\mathrm{mm}^{2}\right)$} & \multirow{2}{*}{ Difference (\%) } \\
\cline { 2 - 3 } & Shell Element & Basic Strip & 9.35 \\
\hline $\mathbf{4}$ & 4985.8 & 5451.82 & 10.57 \\
\hline $\mathbf{1}$ & 12760.5 & 14108.66 & \\
\hline
\end{tabular}

Tab. 15. The effective area of the infill plates, 13 -story SPSW frame with bay width of $3 \mathrm{~m}$

\begin{tabular}{cccc}
\hline \multirow{2}{*}{ Level } & \multicolumn{2}{c}{ Plate area perpendicular to the direction of tension field $\left(\mathrm{mm}^{2}\right)$} & \multirow{2}{*}{ Difference (\%) } \\
\cline { 2 - 3 } & Shell Element & Basic Strip & 13.14 \\
\hline $\mathbf{1 3}$ & 6273.47 & 7098.1 & 39.34 \\
\hline $\mathbf{7}$ & 34400.08 & 47934.02 & 43.43 \\
\hline $\mathbf{1}$ & 44592.24 & 63957.46 & \\
\hline
\end{tabular}

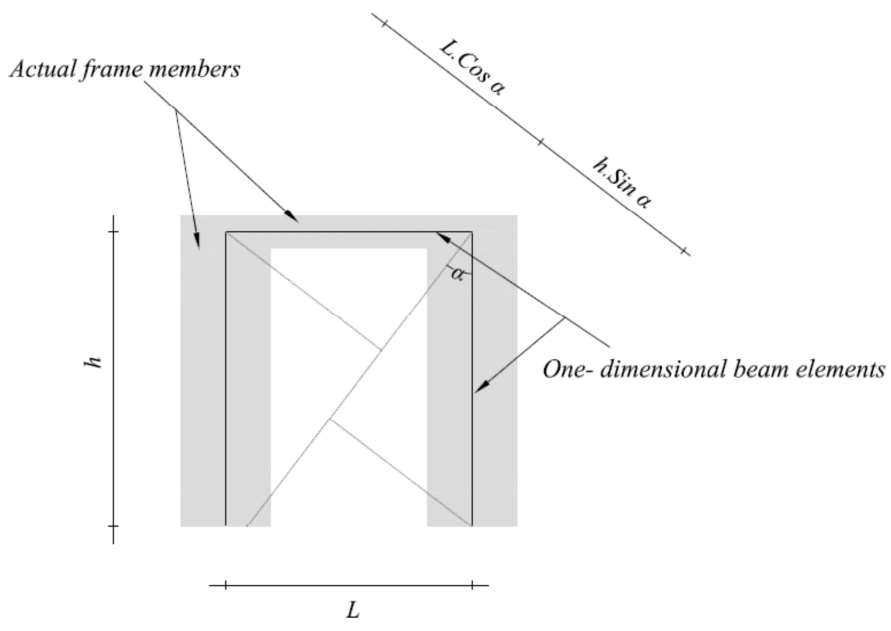

Fig. 16. The dimensional proportions of frame members and infill plate

- Panel zones have an important effect on the response of SPSW frames; and should be modeled as effectively rigid regions in the strip model. The RBS connection, on the other hand, has little effect on the global behavior of SPSWs.

- As the slenderness ratio of boundary frame members increases beyond the limit defined for the beam elements, the accuracy of the results obtained via the strip method reduces. In such cases, modeling with the shell element method may be preferable to obtain more accurate results.

- Although the modified strip method improves the pushover path results, the VBEs' internal forces are better predicted via the basic strip method. Further research is required to obtain a modified strip model that would provide accurate predictions in both design forces of VBEs and the pushover behavior of SPSW frames.

- The distribution of story shear between infill plates and frame members are quite different in the strip and the shell element methods. The shear contribution of infill plates is higher in the strip method.

\section{References}

1 Troy R, Richard R, Steel plate shear walls resist lateral load, cut costs, Civil Engineering, ASCE, 49(2), (1979), 53-55.
2 Timler P, Ventura CE, Prion H, Anjam R, Experimental and analytical studies of steel plate shear walls as applied to the design of tall buildings, The Structural Design of Tall Buildings, 7(3), (1998), 233-249, DOI 10.1002/(SICI)1099-1794(199809)7:3<233::AID-TAL111>3.0.CO;2-I

3 Timler PA, Ventura CE, Proceedings of North American Steel Construction Conference; Toronto, Canada, 1999.

4 Astaneh-AsI, A Seismic behavior and design of steel shear walls, Structural Steel Educational Council, Technical Information and Product Service; Berkeley, USA, Steel Tips, 2001.

5 Behbahanifard MR, Grondin GY, Elwi AE, Experimental and numerical investigation of steel plate shear wall, University of Alberta, Department of Civil and Environmental Engineering; Edmonton, Alberta, Canada, 2003. Structural Engineering Report No. 254.

6 Park H-G, Kwack J-H, Jeon S-W, Kim W-K, Choi I-R, Framed Steel Plate Wall Behavior under Cyclic Lateral Loading, Journal of Structural Engineering, 133(3), (2007), 378-388, DOI 10.1061/(ASCE)07339445(2007)133:3(378)

7 Habashi HR, Alinia MM, Characteristics of the wall-frame interaction in steel plate shear walls, Journal of Constructional Steel Research, 66(2), (2010), 150-158, DOI 10.1016/j.jcsr.2009.09.004

8 Gholipour M, Alinia MM, Considerations on the Pushover Analysis of Multi-Story Steel Plate Shear Wall Structures, Periodica Polytechnica Civil Engineering, 60(1), (2016), 113-126, DOI 10.3311/PPci.7706

9 Kharrazi MHK, Prion HGL, Ventura CE, Implementation of M-PFI method in design of steel plate walls, Journal of Constructional Steel Research, 64(4), (2008), 465-479, DOI 10.1016/j.jcsr.2007.09.005

10 Bhowmick AK, Driver RG, Grondin GY, Seismic analysis of steel plate shear walls considering strain rate and -delta effects, Journal of Constructional Steel Research, 65(5), (2009), 1149-1159, DOI 10.1016/j.jcsr.2008.08.003

11 Bhowmick AK, Grondin GY, Driver RG, Estimating fundamental periods of steel plate shear walls, Engineering Structures, 33(6), (2011), 1883-1893, DOI $10.1016 / j$.engstruct.2011.02.010

12 Thorburn L, Kulak G, Montgomery C, Analysis of steel plate shear walls, University of Alberta, Department of Civil and Environmental Engineering; Edmonton, Alberta, Canada, 1983. Structural Engineering Report No. 107.

13 Timler PA, Kulak GL, Experimental study of steel plate shear walls, University of Alberta, Department of Civil and Environmental Engineering; Edmonton, Alberta, Canada, 1983. Structural Engineering Report No. 114.

14 Tromposch EW, Kulak GL, Cyclic and static behaviour of thin panel steel plate shear walls, University of Alberta, Department of Civil and Environmental Engineering; Edmonton, Alberta, Canada, 1987. Structural Engineering Report No. 145.

15 Lubell AS, Performance of unstiffened steel plate shear walls under cyclic 
quasi-static loading, MSc Thesis, University of British Columbia, Department of Civil Engineering; Canada, 1995.

16 Driver RG, Kulak GL, Elwi AE, Kennedy DJL, FE and Simplified Models of Steel Plate Shear Wall, Journal of Structural Engineering, 124(2), (1998), 121-130, DOI 10.1061/(ASCE)0733-9445(1998)124:2(121)

17 Limit state design of steel structures, Canadian Standard Association; Ontario, Canada, CSA-S16, 2009.

18 Seismic provisions for structural steel buildings, American Institute of Steel Construction; Chicago, Illinois, AISC-341, 2010.

19 Berman JW, Seismic behavior of code designed steel plate shear walls, Engineering Structures, 33(1), (2011), 230-244, DOI 10.1016/j.engstruct.2010.10.015

20 Gholipour M, Asadi E, Alinia MM, The use of outrigger system in steel plate shear wall structures, Advances in Structural Engineering, 18(6), (2015), 853-872, DOI $10.1260 / 1369-4332.18 .6 .853$

21 SAP2000 nonlinear, Computers and structures Inc.; USA, 1984-2000.

22 Minimum design loads for buildings and other structures, American Society of Civil Engineers; Reston, Virginia, ASCE-7, 2010.

23 Specification for structural steel buildings, American Institute of Steel Construction; Chicago, Illinois, AISC-360, 2010.

24 ABAQUS theory manual, HKS Inc.; USA, 2010.

25 Steel design guide 20, American Institute of Steel Construction; Chicago, Illinois, AISC-820, 2007.

26 Driver RG, Kulak GL, Kennedy DJL, Elwi AE, Cyclic Test of Four-Story Steel Plate Shear Wall, Journal of Structural Engineering, 124(2), (1998), 112-120, DOI 10.1061/(ASCE)0733-9445(1998)124:2(112)

27 Shishkin J, Driver R, Grondin G, Analysis of steel plate shear walls using the modified strip model, University of Alberta, Department of Civil and Environmental Engineering; Edmonton, Alberta, Canada, 2005. Structural Engineering Report No. 261.

28 State of the art report on connection performance, Federal Emergency Management Agency; Washington, D. C., FEMA-355 D., 2000. 